University of Louisville ThinkIR: The University of Louisville's Institutional Repository

Electronic Theses and Dissertations

$12-2015$

\title{
Plant community responses to invasive shrub and vine removal in an urban park woodland.
}

Eric Richard Moore

University of Louisville

Follow this and additional works at: https://ir.library.louisville.edu/etd

Part of the Other Ecology and Evolutionary Biology Commons, Other Plant Sciences Commons, and the Plant Biology Commons

\section{Recommended Citation}

Moore, Eric Richard, "Plant community responses to invasive shrub and vine removal in an urban park woodland." (2015). Electronic Theses and Dissertations. Paper 2305.

https://doi.org/10.18297/etd/2305

This Master's Thesis is brought to you for free and open access by ThinkIR: The University of Louisville's Institutional Repository. It has been accepted for inclusion in Electronic Theses and Dissertations by an authorized administrator of ThinkIR: The University of Louisville's Institutional Repository. This title appears here courtesy of the author, who has retained all other copyrights. For more information, please contact thinkir@louisville.edu. 
PLANT COMMUNITY RESPONSES TO INVASIVE SHRUB AND VINE REMOVAL IN AN URBAN PARK WOODLAND

\author{
By \\ Eric Richard Moore \\ B.S., University of Louisville, 2013

\begin{abstract}
A Thesis
Submitted to the Faculty of the

College of Arts and Sciences of the University of Louisville

in Partial Fulfillment of the Requirements

for the Degree of
\end{abstract}

Master of Science in Biology

Department of Biology

University of Louisville

Louisville, Kentucky

December 2015 

PLANT COMMUNITY RESPONSES TO INVASIVE SHRUB AND VINE REMOVAL IN AN URBAN PARK WOODLAND

\author{
By \\ Eric Richard Moore \\ B.S., University of Louisville, 2013 \\ A Thesis Approved on
}

November 20, 2015

by the following Thesis Committee:

Dr. Margaret Carreiro, Director

Dr. Susanna Remold

Mr. Major Waltman 


\section{ACKNOWLEDGEMENTS}

I would like to thank my adviser Dr. Margaret Carreiro for her advice, guidance, engaging lectures, passion, and patience; Dr. Susanna Remold for statistical guidance and instilling in me an appreciation for biological statistics; Major Waltman and the Louisville Olmsted Parks Conservancy for developing this project, providing funding, and for their continued management and stewardship of Louisville's Olmsted Parks; to my undergraduate assistant Shane Stiles, who assisted daily with data collection and plant identification, and Jenna Lyons for her help locating plots and collecting data when possible; and to my parents, family, and friends, for their continued and unwavering support during the last two years. 


\title{
ABSTRACT \\ PLANT COMMUNITY RESPONSES TO INVASIVE SHRUB AND VINE REMOVAL IN AN URBAN PARK WOODLAND
}

\author{
Eric R. Moore
}

November 20, 2015

Counter to what some people think, urban areas can be biodiversity hotspots. Maintaining this biodiversity can be challenging, since exotic shrubs and vines block sunlight and threaten native plant regeneration. Since 2007, the Louisville Olmsted Parks Conservancy (LOPC) has spent \$2 million on invasive plant management in Cherokee Park. Before the project began, long-term transects were established by the LOPC to collect baseline presence/absence data on 11 invasive plant species. In 2014, I revisited these transects and documented presence/absence data on the entire plant community. I found that four species (garlic mustard, winter creeper, Japanese honeysuckle, and English ivy) have increased significantly since 2007, while only one species (ground ivy) has declined. However, native plant taxa, including some rare species, represented twothirds of the total plant community. This information will allow managers to focus their efforts on areas where invasive plants are problematic or where rare native species are present. 
TABLE OF CONTENTS

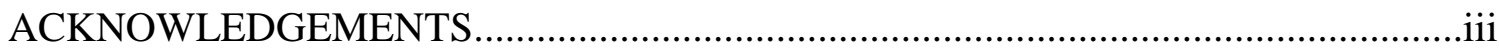

ABSTRACT

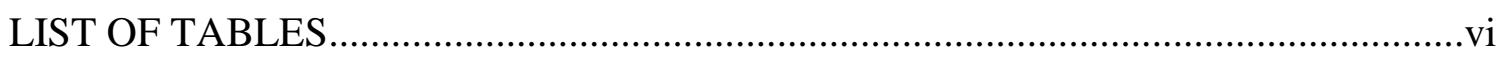

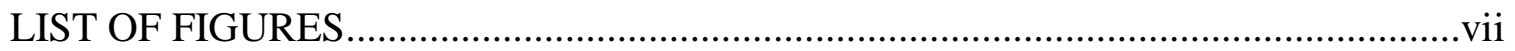

INTRODUCTION

METHODS

RESULTS

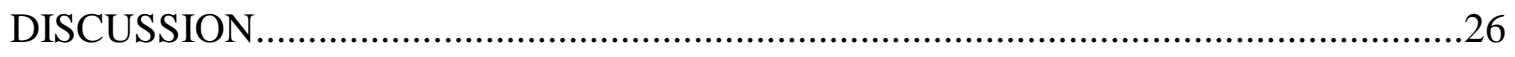

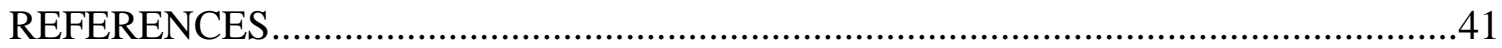

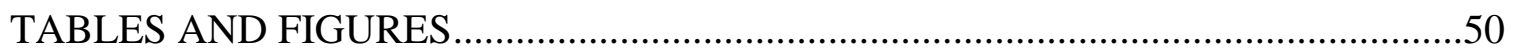

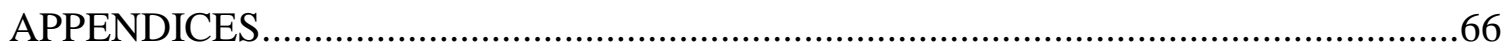

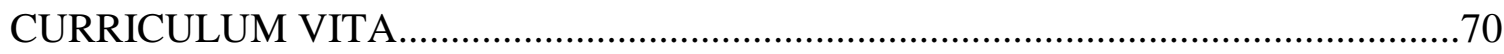




\section{LIST OF TABLES}

Table 1. List of 11 Invasive Species.......................................50

Table 2. Invasive species frequencies and rankings for 2007 and $2014 \ldots \ldots \ldots \ldots \ldots . \ldots 51$

Table 3. Net change of invasive species frequency from $2007-2014 \ldots \ldots \ldots \ldots \ldots \ldots . .52$

Table 4. 2014 Plant species with Coefficients of Conservatism (CV) > 5 ............53

Table 5. Combined Community: CCA axis summary and biplot scores..............54

Table 6. Combined Community: Canonical Coefficients........................55

Table 7. Invasive Community: CCA axis summary and biplot scores...............56

Table 8. Invasive Community: Canonical Coefficients...........................57 


\section{LIST OF FIGURES}

Figure 1. Cherokee Park Management Areas....................................58

Figure 2. Transect Locations in Cherokee Park................................59

Figure 3. Frequency distribution of invasive species density, 2007-2014..........60

Figure 4. CCA Ordination: Combined Community, Axis $1 \& 2 \ldots \ldots \ldots \ldots \ldots \ldots . \ldots 6$

Figure 5. CCA Ordination: Combined Community, Axis $1 \& 3 \ldots \ldots \ldots \ldots \ldots \ldots . \ldots 6$

Figure 6. CCA Ordination: Combined Community, Axis $2 \& 3 \ldots \ldots \ldots \ldots \ldots \ldots \ldots$

Figure 7. CCA Ordination: Invasive Community, Axis $1 \& 2 \ldots \ldots \ldots \ldots \ldots \ldots \ldots 4$

Figure 8. CCA Ordination: Invasive Community, Axis $2 \& 3 \ldots \ldots \ldots \ldots \ldots \ldots \ldots \ldots$ 


\section{INTRODUCTION}

Invasive species have become one of the biggest threats to biodiversity in our modern era, second only to habitat loss and fragmentation (Walker and Steffen 1997). In the coming decades, management and control of the spread of invasive species may pose the biggest threat to conservation (Allendorf \& Lundquist 2003), especially as globalization continues to increase the propagule pressure and rate of species invasions worldwide (Hulme 2009). In the United States alone, an estimated 5000 exotic plant species originally cultivated for ornamental or agricultural purposes have become naturalized or invasive in surrounding ecosystems (Pimentel et al. 2005). One analysis of nearly 650 plants native to the continental United States, found that invasive plant species were directly responsible for the decline of $30 \%$ of all threatened, endangered, or possibly extinct native plant species (Wilcove et al. 1998). Furthermore, costs associated with losses and damages due to invasive species, along with management and control efforts, approach an estimated $\$ 35$ billion annually, though this does not account for the even larger cost of the ecosystem services that may be affected (Pimentel et al. 2005).

Urban areas in particular (Alvey 2006; Maskell et al. 2006; Huebner et al. 2012;

Golivets 2013; Nielsen et al. 2013) are strongly associated with higher species richness of non-natives and lower species richness of natives. Cities inherently offer many pathways for dispersal of these exotic species, and through anthropogenic activities we have facilitated the spread of invasive species into more natural ecosystems along the urban- 
rural gradient (Kowarik 2011; Huebner et al. 2012). This does not necessarily mean that diversity and function of the ecosystem and the services provided have been lost-rather, urban parks and forests have been found to be hotspots of biodiversity, and may contain better quality habitat than degraded, fragmented remnants of the historical ecosystem located elsewhere (Alvey 2006). Consequently, parks can act as a refuge for rare and endangered native species, as long as the park is large enough and these species are able to tolerate a certain degree of disturbance and fragmentation (Alvey 2006; Huebner et al. 2012). Overall, species richness is typically higher in urban parks than in surrounding rural areas, but they contain many more exotic than native plant species. Studies on longterm changes in plant species taxa have attributed this to an increase in novel invasive plant species that far outweighs the loss of native plant species over time (Drayton and Primack 1996; DeCandido 2004).

\section{Establishment and Plant Communities of Cherokee Park}

Plans to establish an urban park in Louisville, Kentucky, came to fruition in 1890. The following year, the firm of distinguished landscape architect, Frederick Law Olmsted, was commissioned to design what would become the 166 ha Cherokee Park. Within two years, nearly 18,000 trees and shrubs had been planted in the park, although not all were native to the ecosystem (Carreiro and Zipperer 2011). Ironically, the original design plans called for planting many of the species that have now become invasive in the woodlands. Five of these were targeted for removal as a part of this study. These included the woody vines Euonymus fortunei (wintercreeper) and Hedera helix (English ivy), the herbaceous vine Glechoma hederacea (ground ivy, creeping Charlie), and 
species of honeysuckle, such as Lonicera maackii (Amur/bush honeysuckle; shrub) and L. japonica (Japanese honeysuckle; woody vine) (Carreiro and Zipperer 2011). Other species that were assessed during this study, such as Celastrus orbiculatus (Asian bittersweet) and Alliaria petiolata (garlic mustard) arrived sometime later in the $20^{\text {th }}$ century (Haragan 2014).

After the Olmsted firm ceased consulting on the management of plant communities in 1934, Cherokee Park entered into a 40-year period of deferred management. Decisions were made to focus on providing recreational sports opportunities in the park, which left its woodlands essentially neglected. This allowed introduced plant species to become more pervasive. The creation of Interstate 64 in the 1960s, and the two tunnels that were needed to route it underneath the park's northern edge, added to the propagule pressure of exotic species, such as Lonicera maackii, planted along the highway verge (Trammell and Carreiro, 2011). It wasn’t until a powerful EF-4 tornado in 1974 destroyed $75 \%$ of the park's mature trees that the full extent of degradation became apparent and worsened (Carreiro and Zipperer 2011). While this event prompted the Louisville community to act with urgency, two years passed before most new trees were planted. Light availability to the once shaded understory had increased dramatically, and as fallen trees were removed the soil was disturbed. This created conditions that favor germination and growth of weedy species, including a suite of invasives that existed in the seed and root bank. In 1976, 2200 trees and 5000 shrubs (unfortunately including invasive Lonicera species) were planted, but without the necessary funds for long-term management, and with a management philosophy that "nature would heal itself now" (Anita Solomon, pers. comm.), invasive 
shrubs and vines overtook tree growth. In the absence of a mature canopy, the invasive shrubs and vines became abundant in the woodlands. Over time, tree seedlings and saplings declined from the understory layer, threatening the future of the forest itself. The condition of the park could no longer be ignored by the city, and in 1989, the newly formed Louisville Olmsted Parks Conservancy (LOPC) partnered with Metro Parks in managing the parks. This allowed the LOPC to focus full-time on the management of natural areas within the Cherokee Park and other Olmsted Parks around the city, as well as to acquire funds via donations and grants for this purpose.

In the winter of 2007-2008, an ambitious woodland restoration project was initiated to restore native plant diversity by eradicating invasive shrubs (mostly Lonicera species) and woody vine species. By 2011 this project was $90 \%$ complete, and stark differences in light availability and density of understory vegetation were quite visible. To date, the LOPC has spent over $\$ 2$ million on Cherokee Park alone to achieve this goal (Major Waltman, pers.comm.), resulting in significant increases in tree seedling and sapling abundance (Moore et al., unpubl. data 2013), as well as increases in native plant diversity as a whole (Carreiro 2014).

In 2007, before starting the invasive removal campaign, LOPC established longterm transects for documenting the presence-absence of 11 invasive species of great concern in the park. Long-term monitoring of their distributions is just as important as the initial removal. Light availability from the removal of large amounts of vine and shrub biomass could stimulate not only the growth of native species but these invasives themselves. Therefore, the goals of this study, conducted 7 years later in 2014, were to 1) quantify the changes in frequency and distribution of these 11 invasive plants in response 
to this large-scale woodland restoration, 2) establish a baseline for native species and other non-natives in these same transects, 3) assess the conservation quality of these native species using the Coefficient of Conservatism Values for Kentucky Plants, and 4) determine the extent to which some native species may be currently co-existing with the 11 invasive species. 


\section{METHODS}

\section{Definitions}

Throughout this thesis, the term "invasive species" will refer only to the 11 species that the Louisville Olmsted Parks Conservancy (LOPC) considered important threats to native plant diversity in the Louisville Park System (Table 1). However, the United States Department of Agriculture (USDA) defines an invasive species as "any species not native (exotic) to the ecosystem under consideration, and whose introduction causes or is likely to cause economic or environmental harm, or harm to human health," as set forth in Executive Order 13112 (Beck et al. 2006). Exotic species that have been described as invasive in the literature, but were not on the list of 11 invasive species of special concern, will simply be referred to as "non-native" or "exotic." More generally, those species that were not one of the 11 invasive species of concern are termed "noninvasive," which includes both native and exotic species.

Study Site

Cherokee Park is located in the city of Louisville, $\mathrm{KY}\left(38.25^{\circ} \mathrm{N}, 85.77^{\circ} \mathrm{W}\right)$, which has a population of 741,096 (US Census Bureau 2010), with woodlands comprising 78 of its 166 ha. The woodlands are characterized by deep, well-drained soils under mesic conditions, with average annual precipitation of $113 \mathrm{~cm}$, and distributed evenly throughout the year (Pipal 2014). The region experiences warm, humid summers 
(mean temperature around $26^{\circ} \mathrm{C}$ ) and cool winters (mean temperature of $0.5^{\circ} \mathrm{C}$ ), with a mean annual temperature of $14^{\circ} \mathrm{C}$ (Pipal 2014).

The park was divided into 10 management areas of various sizes and characteristics (Figure 1), so that the Louisville Olmsted Parks Conservancy (LOPC) could develop specific plans for managing each of these areas. Over the last 10 years, management has largely focused on removal of invasive species and restoration of the woodlands via removals and the planting of native species, particularly trees. Many of these invasive, exotic plants have been established in the park for decades, especially after the tornado event in 1974. Since 2007, the LOPC has spent over \$2 million on woodland restoration projects aimed at controlling and eradicating these invasive species, as well as monitoring and planting native species. The study described here is part of a long-term monitoring project that was initiated in 2007 by the LOPC, prior to the parkwide removal of the invasive, exotic shrub honeysuckle, Lonicera maackii, and several species of mostly exotic woody vines. These removals began late in 2007 , and were $90 \%$ complete by 2011.

\section{Experimental Design}

In 2007, before starting the large-scale invasive plant removal campaign, the LOPC established permanent transects in all ten management areas of the woodlands for long-term monitoring of the plant community. The starting position of each transect (hereafter referred to as the pin) was chosen carefully, or as McCune and Grace (2002) suggest, "with arbitrary but with pre-conceived bias," such that each pin (and the resulting transect) was more likely to be located in the interior of the woodland and away 
from roads or fields used for recreation. Transects still extended to the woodland edge on occasion. Each pin was first mapped by management area, and coordinates entered using ESRI ArcGIS 9.2. The resulting shapefile of pin locations was loaded onto a portable GPS unit (Trimble GeoExplorer) and taken into the field to find their precise location. A piece of steel rebar was then driven into the ground to permanently mark each of these locations and painted orange for visibility. In the Bonnycastle Hill and Wildflower Woods areas, consecutive pins were placed $12.5 \mathrm{~m}$ apart, but this distance was adjusted to $25 \mathrm{~m}$ for all other areas except for Beal's Branch $(50 \mathrm{~m})$ so as to cover large areas with greater speed.

To determine the direction, or bearing, for each transect, the researcher stood at the pin's location, pointed a compass at the next pin in the sequence, and recorded the pin-to-pin heading in degrees from north. Next, a fair coin was flipped, and the result (heads or tails) was used to calculate the transect bearing as follows:

Heads: bearing $=$ heading $+90^{\circ}$

Tails: bearing $=$ heading $-90^{\circ}$

A $50 \mathrm{~m}$ measuring tape was used to measure transect length and ensure that each one was straight. Some transects extended to the maximum length of $50 \mathrm{~m}$, but many were stopped short by roads, woodland edges, creeks, or streams; therefore, transect length varied as determined by these barriers. After establishing the transect, $1 \mathrm{x} 1 \mathrm{~m}$ quadrats were spaced at $5 \mathrm{~m}$ intervals along the transect following an interrupted belt transect design. To determine the starting location of the first quadrat in each transect, a random number generator was used to generate an integer from 0 to 50 decimeters ( 0 to 5 m). Quadrats were always placed along the right side of transects, with one quadrat 
corner at the randomly generated distance and another corner 1 meter farther along the transect (Figure 2).

\section{Field Data Collection}

Baseline data were collected prior to the start of the invasive plant removal campaign by LOPC woodlands management staff, from June to September of 2007. Each quadrat was assessed for the presence or absence of each of the eleven invasive species of interest. Dead but identifiable plants were counted as present. Data on the presence or absence of other plant species, as well as canopy cover, were not collected in 2007.

From May to September 2014, the original transects were relocated using a Trimble GPS unit (Trimble GeoExplorer 6000) and quadrats were re-sampled for presence/absence of the same eleven invasive plants surveyed in 2007, as well as the presence of all other plant species within the $1 \mathrm{~m}^{2}$ quadrat. In addition, the Beal's Branch management area was also added to the study and sampled during this time, bringing the total number of management areas included in the study to ten. Percent canopy cover at each quadrat was also measured using a convex densiometer (Lemmon 1956) as follows. Four measurements of canopy cover at each quadrat side were taken from waist height, then averaged and reported as PercentCanopyCover. Plants were identified to species when possible, using Haragan (2014). No distinction was made between seedling and sapling, or juvenile and adult, or between different stages of a species' life cycle (e.g. $1^{\text {st }}$

or $2^{\text {nd }}$ year for biennial species). For cases in which a genus was represented by at least 2 identifiable species, but the majority of individuals could not be keyed to species due to lack of flowers or other defining characteristics, plants were only keyed to genus (e.g. 
Impatiens spp. and Solidago spp.). Graminoids (grasses, rushes, and sedges) were keyed to their respective families, and mosses and ferns were grouped at the phylum level (Bryophyte and Pteridophyta, respectively). Because of this, species richness has been conservatively estimated and the level of analyses is often described as performed at the taxon level.

Data Collection for Geographic Information System (GIS) Analyses

For geoprocessing workflows, ModelBuilder was used in ArcGIS 10.2.2 to clip features and project from different spatial references. For example, park management areas, trails, annual mowing zones, and the starting location of each transect were clipped to the Cherokee Park boundary and projected from the NAD_1983_StatePlane_Kentucky_North_FIPS_1601_Feet (or similar) spatial reference to NAD_1983_UTM_Zone_16N, so as to convert units from feet to meters. The same process was also used for GIS data from the Louisville/Jefferson County Information Consortium (LOJIC) geodatabase, which included roads, water features, flood zones, and a $5 \mathrm{ft}$. resolution DEM (Digital Elevation Model) that was used to generate rasters of aspect (degrees from north), slope (in degrees), and elevation (in meters above sea level). Transect lines and quadrat polygon feature classes were created in ArcGIS 10.2.2, so that the environmental variables (Aspect, Slope, and Elevation) and species presence/absence information could then be joined to each respective quadrat and spatially represented. Trails were buffered by $1 \mathrm{~m}$, since field accuracy of the Trimble GeoExplorer 6000 was usually around $3 \mathrm{ft}$. Distances from each quadrat to the nearest trail (TrailDis), annual mow zone (MowZnDis), and flood zone (FloodDis) were calculated. The categorical 
variables Trail, MowZone, and Flood were also created to distinguish between quadrats that were located either inside or outside of these zones. The flood zone layer was provided by LOJIC and depicts areas that are within the 500-year flood plain. This was chosen due to the fact that heavy rain events over the past few years have inundated areas within the 500-year flood plain on more than one occasion.

\section{Statistical Data Analysis}

Invasive Species Responses to Invasive Shrub and Vine Removal (2007 vs. 2014)

Before beginning this analysis, a number of mislabeled transects, along with the newly added Beal's Branch area, were removed, because they had not been sampled in both years. Thus, sample size was reduced from 629 to 497 quadrats for comparing invasive species frequency before and after invasive shrub and vine removal. To determine if the mean invasive species richness per quadrat had changed since management efforts began in late 2007, the Wilcoxon signed-rank test was used in SAS 9.4 to determine if differences in mean Invasive Species Richness per quadrat $\left(\bar{S}_{\text {inv }}\right)$ in 2007 and 2014 were detectable. This non-parametric test was chosen over the analogous paired $t$-test since it does not make assumptions of normality or require that differences between paired observations be normally distributed.

To determine whether or not the frequencies of each invasive species had significantly changed from 2007 to 2014, Wilcoxon's signed-rank test was performed in SAS 9.4 on all species except A. altissima and A. quinata, which did not occur often enough in either year to qualify for analysis (fewer than 20 quadrats could lead to an approximation that increases type II error). The remaining 9 species were analyzed for 
significant changes in frequency between 2007 and 2014, then corrected for multiple comparisons using the Benjamini-Hochberg procedure. This method is preferred over the more conservative Bonferroni procedure, because Bonferroni corrections can increase the probability of type II errors (Benjamini and Hochberg 1995), which may in turn allow managers to more easily overlook an invasive species threat and not take timely action to prevent further spread.

\section{Community Analysis}

Mean species richness per quadrat of invasives $\left(\bar{S}_{\text {inv }}\right)$, non-invasives $\left(\bar{S}_{\text {other }}\right)$, and all plants combined $\left(\bar{S}_{\text {total }}=\bar{S}_{\text {inv }}+\bar{S}_{\text {other }}\right)$, was calculated for the entire park, then for each of the 9 aspect classes, and finally for each type of disturbance zone to determine if aspect and disturbances affected species density of these three community groups. Welch's ANOVA and Welch's t-test analyses were performed using SAS 9.4. Welch's ANOVA, which is robust where large differences in sample sizes and unequal variance occur, was used to compare species richness values among the aspect classes. Welch's ttest, which Ruxton (2006) suggests for use over the student's t-test, was used to compare species richness between quadrats within vs. outside of flood zones, and within 1 meter

of a trail vs. not near a trail. The number of quadrats located in a mow zone $(24,3.8 \%$ of all quadrats) was not compared statistically with those not in a mow zone due to the low sample size of mowed quadrats.

Coefficients of Conservatism Values for Kentucky $(C V)$ were assigned to each native species according to the work done by Shea et al. (unpublished). These values provide an assessment of each species' quality (rarity being one factor) within the 
ecosystem, and its ability to survive or tolerate habitats in varying degrees of degradation. Values range from 0 to 10 , with low values indicating a ruderal and common species able to withstand high levels of anthropogenic and natural disturbance, while higher values are assigned to species that are only found in higher quality, less disturbed natural areas, or rare habitats. The mean, median, and mode of $C V$ was calculated to describe the overall quality of the native species community within this urban park woodland.

To understand relationships among all plant species in the woodland, and whether species presence could be related to selected environmental variables, Canonical Correspondence Analysis (CCA) was performed using PC-ORD (Version 6.08). Taxonomic presence/absence data of the 2014 plant community (main matrix) was entered along with the environmental variables measured in each of the 629 quadrats used for this analysis (explanatory matrix). The initial quadrat-by-taxon matrix was reduced from 123 taxonomic units to 33 taxa (including 26 distinct species) using the recommended criterion that a taxon must be present in at least $5 \%$ of sampled quadrats (31 quadrats) to eliminate the effects that rare species have in masking relationships between environmental variables and more common species (McCune and Grace 2002). Since CCA cannot be performed when quadrats contain zero species, a "dummy" species was created and counted as present in every quadrat, allowing "empty" quadrats to be included in the analysis (McCune and Grace 2002; Peck 2010). The matrix was further modified to create two additional matrices: one that contained only the native species ( 22 species), and another that contained only invasive species ( 9 species). Ordination was then performed on all three of these quadrat-by-taxon matrices, using the same matrix of environmental variables for each analysis. 
Only the quantitative variables are used when performing CCA; categorical variables, such as mow zones, flood zones and aspect, are ignored. However, they can still be used as a grouping variable in the 2-D output of the ordination (e.g. by coloring quadrats in a flood zone one color, and those outside of the flood zone a different color). Continuous variables do not need to be transformed to meet assumptions of normality, but McCune and Grace (2002) state that datasets can still benefit from transformations if, for example, informative species or variables emphasized at the expense of uninformative ones, or an ordination's associated distance measure is not compatible with the dataset. Since \% canopy cover was very negatively skewed in this study (mostly high values of canopy cover due to the nature of woodland study sites), the few quadrats that had open canopy cover were flagged by PC-ORD as outliers, and it was suggested that they be transformed or removed from the dataset. Inspection of these quadrats found high frequencies of Ampelopsis brevipedunculata and short distances from annual mow zones, both of which explain real patterns in the data. The decision was made to keep these quadrats, but \% canopy cover was transformed using the inverse-reflected transformation, and the resulting variable named invRefCC, produced a positively skewed distribution that greatly reduced the effect of these outliers. Aspect was transformed from a single, circular variable in units of degrees from North, into two variables (Morrison et al. 2003): Northness $=\cos ($ Aspect $)$ and Eastness $=\sin ($ Aspect $)$. This resulted in an explanatory matrix with seven variables: Northness, Eastness, invRefCC, SlopeDeg, TrailDis, FloodDis, and MowZnDis.

Before running CCA, the user must specify a few settings that determine how the resulting ordination scores are calculated and displayed. Following the recommendations 
of McCune and Grace (2002) for ecologically interpretable ordinations, settings were as follows: Row and Column Scores were set to "Standardize by Centering and Normalizing"; Ordination Scores were set to "Scale by Optimizing Columns" (species); Scores for Graphing Quadrats in Ordination Space were computed as Linear Combinations (LC) of variables. Monte-Carlo randomization tests were performed 999 times to test the null hypothesis of "No linear relationship between matrices," which returns a $\mathrm{P}$-value for each of the three axes; if $\mathrm{P}<0.05$, we reject the null hypothesis and conclude that there is indeed a real relationship between the species data and the variables.

In the Graph Ordination Options, plexus values were used to identify associations among species at two levels as determined by their chi-square distance, weak (cutoff $=0.2$ ) and strong (cutoff $=0.25$ ). This procedure places lines on the ordination bi-plot connecting species that are positively associated with one another. Categorical grouping variables were used to identify quadrats that tended to belong to particular groups by drawing convex hulls around those quadrats in the bi-plot. In this way the location of quadrats within mow zones, for example, could be visualized. After examining the results of the ordination, Northness was removed because it failed to explain much of the variation in any of the axes, indicating a weak relationship to the species data. 


\section{RESULTS}

Before-and-After Analysis: Invasive Species Responses to Shrub and Vine Removal

Analysis of presence/absence data from the 497 quadrats sampled in 2007 before shrub and vine removal and again in 2014 revealed that, in spite of management efforts, the mean number of invasive species per quadrat $\left(\bar{S}_{\text {inv }}\right)$ increased from 1.60 in 2007 to 1.99 in $2014(\mathrm{P}<0.001)$. In 2007, half of all quadrats had either 0 or 1 invasive species per quadrat. The median and the mode for 2007 was 1 invasive species per quadrat, representing $38 \%$ of quadrats. However, 7 years after these removals, there was a shift toward increased invasive species density throughout the park $(\mathrm{P}<0.0001 \mathrm{using}$ Wilcoxon's sign-ranked test; Fig. 3). While the number of quadrats with only 1 invasive species decreased by $32 \%$, the number of quadrats containing 3 invasive species per quadrat increased by $52 \%$, and the number with 4 or more invasives increased $162 \%$.

The coefficient of dispersion, which is a measure of how well a set of observations fit a given frequency distribution, was less than 1 in both years $\left(C D_{2007}=0.679 ; C D_{2014}=0.895\right)$, which may indicate that invasive species did not tend to co-occur at the scale of $1 \mathrm{~m}^{2}$. However, the higher CD in 2014 corroborates that mean invasive species richness per quadrat (species density) had increased in 2014.

While invasive species abundance increased overall during the interval, abundance responses differed by species. In 2007, Glechoma hederacea was the most frequently found invasive (29\% of all quadrats), followed by Vitis spp. (26\%), and $L$. 
japonica (23.7\%; Table 2). However, in 2014 G. hederacea exhibited a large decrease (down to $18.7 \%$ of quadrats), declining in frequency ranking to 5th place. Vitis sp. also declined in abundance and ranking. On the other hand, A. petiolata increased from $16.9 \%$ to $38 \%$ frequency, exhibiting the largest response increase of all invasives and becoming the most encountered species in 2014. Euonymus fortunei and L. japonica also increased, and while $L$. japonica did not move from $3^{\text {rd }}$ place, E. fortunei moved from $4^{\text {th }}$ to $2^{\text {nd }}$ place.

Analysis of net change in presence shows that the increase in frequency made by A. petiolata alone (105 quadrats) exceeded total net decreases in frequency (69 quadrats) of the 4 species that declined. After adjusting for multiple comparisons, significant increases in presence were observed for A. petiolata $(\mathrm{P}<0.001)$, E. fortunei $(\mathrm{P}<0.001), L$. japonica $(\mathrm{P}=0.015)$, and H. helix $(\mathrm{P}=0.014)$, while G. hederacea was the only species to significantly decrease $(\mathrm{P}=0.001)$. Remaining species (A. altissima and A. quinata) were not found frequently enough to support significance testing; Table 3).

\section{Plant Community Analysis}

In the 629 quadrats used for this community analysis, 123 distinct plant taxa from 60 different families were identified (Appendix 1). Of these taxa, 84 (68.3\%) were native to Kentucky, while 39 (31.7\%) were non-native. One-third of all taxa, representing 17 families, were native herbs. This included 13 species in the family Asteraceae alone (11\% of all taxa). Native trees comprised an additional $25 \%$ of all taxa, while native shrubs and vines comprised $6 \%$ and 5\%, respectively. The 30 non-native taxa were distributed across 31 families. Sixteen species of non-native herbs were found (13\% of all taxa), 
representing 14 families. Non-native trees accounted for 5\% of taxa, and shrubs and vines both comprised an additional $6.5 \%$ of all taxa (13\% total). Non-native vine taxa outnumbered native vine taxa 8 to 6 , and were the only non-native group to outnumber their native counterpart.

Mean total species richness $\left( \pm 1\right.$. S. D.) per quadrat $\left(\bar{S}_{\text {total }}\right)$ was $5.94 \pm 2.89$, while mean species richness per quadrat of the 11 target invasive species was $1.96 \pm 1.26$. Species richness of all other non-invasive (natives and non-natives) plants $\left(\bar{S}_{\text {other }}\right)$ was $3.98 \pm 2.39$. The most common ratios of invasives to non-invasives were 2:3 (36 quadrats), 1:5 (34 quadrats), and 1:4 (32 quadrats).

In an effort to determine the overall quality of the native plant community in the woodland, the Coefficient of Conservatism Value (CV; Swink and Wilhelm 1994) was found for all native species in the 2014 plant community. The CV is a state-specific index ranging from 0 to 10 and only applied to native plant species. Weedy common species that are able to tolerate disturbances are given low values, while species that are less common either due to their own life cycle characteristics or because they occur in rarer habitats within a state are given higher values up to a score of 10 . The mean CV ( \pm S.D.) for native plants found in Cherokee Park woodlands was 3.6 \pm 2.0 , with a mode of 2 and a median of 3, indicating a native plant community comprised largely of ruderal and disturbance-tolerant species. There are, however, locations where species that require more stable habitat remain. For example, Allium burdickii (Burdick's leek), with a CV of 8, was found near Beargrass Creek, on flat ground at the bottom of a northeast-facing slope. Six other species with a score of 7 were present across several management areas in the park, most of which were found on northern or northeastern slopes with high 
canopy cover. In all, 32 taxa had scores of 5 or higher (Table 4), representing $37.5 \%$ of all native taxa.

\section{Environmental Variables}

Elevations at the park ranged from 135 - 165 m above sea level. Mean canopy cover of the woodlands was $94.6 \pm 7.7 \%$, with a median of $96.6 \%$. The nine aspect groups were not equally represented; quadrats with west and northwest aspects were the most well-represented, comprising $19.4 \%$ and $18.0 \%$ of all quadrats, respectively. Southeast-facing quadrats were the least represented, comprising only $3.7 \%$ of all quadrats. Despite the higher number of quadrats with west and northwest aspects, Welch's ANOVA found that southeast-facing quadrats had significantly fewer species on average (4.4) than east-facing quadrats $(7.1 ; \mathrm{P} \leq 0.001)$, which had the highest mean species richness of all aspect categories. A total of 233 quadrats (37\%) were found to occupy disturbed areas, which included 182 (29\%) located in flood zones, 51 (8\%) within 1 meter of a trail, and $24(3.8 \%)$ in annual mow zones, with some quadrats located in more than one of these disturbance categories. Welch's t-test found significant differences in mean species density within (6.6 species) vs. outside (5.7) of flood zones $(\mathrm{P}=0.0007)$, but no significant difference in mean species density in quadrats within one meter of a trail (6.0 species) vs. greater than a meter ( 5.9 species) from trails $(\mathrm{P}=0.84)$. Due to the low number of quadrats within a mow zone, univariate analyses was not performed, but proximity to nearest mow zone was still used in ordinations (CCA). 


\section{Canonical Correspondence Analysis}

To understand how the environmental variables above may explain plant community structure, CCA was performed on three different sets of species data. Species that were not found in at least $5 \%$ of quadrats (31 quadrats) were excluded from the ordination, due to the fact that CCA is highly sensitive to rare species, and their occurrence can mask or greatly influence any relationships detected between the environmental variables and community structure. This exclusion subsequently eliminated 90 of the 123 taxa that were found in the community in 2014 . These resulting three species datasets consisted of the "combined community" of 33 native, non-native, and invasive species; the native species community (22 species); and the invasive species (9). Two exotic species that were not considered invasive species were part of the "combined community" of 33 species, and for this reason the native and invasive species communities sum to 31 instead of 33 species. The environmental matrix contained six variables: Eastness, invRefCC, SlopeDeg, TrailDis, FloodDis, and MowZnDis. Eastness was transformed from aspect data and ranged from -1 (west) to 1 (east), while invRefCC was transformed from PercentCanopyCover and ranged from 1 (open canopy) to 2 (closed canopy). CCA automatically relativizes these variables by column before performing the ordination, centering on the mean and standardizing by standard deviation.

Ordination results using the 22 native species were very similar to the ordination results using the 33 native/non-native/invasive species. Therefore, results for only the combined community of 33 species have been reported (Table 4, Table 5). In the combined community, CCA axis 1 explained the most variation (3.2\%), followed by axis 
$2(1.5 \%)$ and axis $3(1.3 \%)$, and a cumulative total of $6 \%$ of variation was explained. Axis 1 was most strongly related to FloodDis and invRefCC, axis 2 was related to Eastness and invRefCC, and axis 3 related to FloodDis and TrailDis. Two-dimensional graphs of the ordination, with species represented as points (refer to Appendix 1 for species identities based on letter codes) with biplot overlays were created, but quadrats are not displayed as they were too numerous and rendered the output indecipherable (Figures 4, 5, and 6).

In Fig. 4 (the combined community, axis 1 vs. axis 2), species with the most negative values on axis 1 (e.g., Verbesina alternifolia, VEAL) cluster together, and are associated with very low canopy cover. They are also very close to at least one of the 3 types of disturbed areas (the floodplain specifically, since FloodDis was strongly related to axis 1). The graph reveals that Ampelopsis brevipedunculata was most commonly found with Solidago spp., in quadrats with low canopy cover, which may be due to annual mowing or location along woodland-field edges. Moving along in the positive $(+)$ direction on axis 1 , toward the center we find species that are increasingly common, and often referred to as generalists or weedy species. The most positive end of axis 1 represents conditions of high percent canopy cover and highest distance from the floodplain. On axis 2, the most negative values represent west-facing quadrats with high exposure to sunlight, and we are likely to find $G$. hederacea or sedges in these quadrats.

Figure 5 (combined community, axis 1 vs. axis 3), shows that the negative end of axis 1 is associated with areas that are close to or within the floodplain and have low percent canopy cover, and according to these ordination results, the invasive Ampelopsis brevipedunculata, the non-native Duchesnea indica, as well as the native Verbesina 
alternifolia are associated with these conditions. Moving in the positive direction along axis 1 , toward less negative values, weedy species associated with lawns and grasses are encountered first, but after passing the origin, the habit shifts from herbs to trees. The most positive values along axis 1 are populated by upland tree species that are furthest from the floodplain and germinate under canopy cover. On axis 3, negative values indicate areas that are farthest from a trail or floodplain. This is an area occupied by Hedera helix, which is known to avoid wet areas (Miller 2006; Swearingen et al. 2010; USDA, NRCS 2015). Increasingly positive values on axis 3 indicate higher degrees of tolerance to these conditions or requirement of moisture as a resource (e.g., natural riparian zones with obligate or facultative wetland species) and disturbances (flooding along Beargrass Creek after frequent, intense, or long-lasting rain events) with the most tolerant being the native tree Prunus serotina.

In Figure 6, the invasive G. hederacea and Viola spp. have the most negative values on axis 2, again indicating west-facing conditions that are not flood prone. Moving along this axis in the positive direction are species that were found closer to a floodplain, and in quadrats with aspect values facing east. East and northeast aspects, which receive their sunlight in the morning, may actually be acting as a surrogate for temperature, humidity, or soil moisture, as aspects facing eastward have lower minimum temperatures and are wetter than the other directions, which are exposed to sunlight during the second half of the day, when temperatures are already warm (Cantlon 1953; Holland and Steyn 1975; Smith 1977; Jones 2013).

Strong associations between species, as determined by the chi-square distance matrix generated during CCA ordination, were observed between the native Pilea pumila 
and the exotic Persicaria maculosa, which are both listed as facultative wetland species by the USDA and occur in wetland or riparian areas in this region. Strong associations between Solidago spp. and Symphyotrichum pilosum were also observed, and they tended to occur in areas that were indicative of woodland edge habitat where sunlight is . Weaker associations were observed between Solidago spp. and A. brevipedunculata; $G$. hederacea and L. japonica; G. hederacea and Impatiens spp.; G. hederacea and Ageratina altissima; and also between Geum canadense and Sedges; Geum canadense and Duchesnea indica; and Geum canadense and A. petiolata.

For the invasive community (Table 7, Table 8), the first axis again explained the most variation (4.7\%), followed by axis $2(2.0 \%)$ and axis $3(1.6 \%)$, with a cumulative $8.2 \%$ of variance explained. Axis 1 was strongly related to distance from a mow zone (MowZnDis) and canopy cover (invRefCC), axis 2 to distance from a trail (TrailDis) and Eastness, and axis 3 to TrailDis and distance from a flood plain (FloodDis). The ordination and biplot overlay (Figures 7, 8, and 9) show that the invasive species community, when examined separately, has a slightly different relationship with the environmental variables than that found in the combined community. Canopy cover and mow zone distance were more influential in predicting the invasive species community, which was mostly explained by the high frequency of A. brevipedunculata and $G$. hederacea in the mow zone.

Figure 7 reveals that canopy cover is a better indicator than the disturbance variables for the presence of $E$. fortunei, which, however, is still associated with less disturbed woodlands. On the other hand, the location of Hedera helix reveals that its presence is more closely associated with increasing distance from disturbance, 
particularly mowed areas and/or the floodplain; however, as a shade tolerant species (Miller 2006; Swearingen et al. 2010; Waggy 2010), it still tends to be associated with locations having high canopy cover. Since both E. fortunei and H. helix tended to cooccur, as the weak association line shows, this information could potentially be useful for deciding if and where to look for one species, if the other is known to be present at a given location. On the positive end of axis 1, A. brevipedunculata is alone, strongly influenced by low canopy and closeness to mowed areas. To a lesser extent, $G$. hederacea appears to be associated with relatively open canopy, close to mowed zones. Negative values on axis 2 represent quadrats that are far from trails but west-facing, while increasingly positive values indicate quadrats with proximity to trails and an eastfacing aspect. The location of $L$. maackii at the positive end of axis 2 indicates that eastfacing quadrats are associated with honeysuckle's presence. Figure 8 (invasive community, axis 2 vs. axis 3) shows this as well, but also indicates that steeper slopes may be more likely than flat or slightly sloped ground to have honeysuckle. There is some evidence that these conditions may be a good predictor of honeysuckle's presence, as Gayek and Quigley (2001) found that L. maackii colonies growing on east facing slopes had significantly larger individuals and higher densities, relative to bottomland $L$. maackii plants. Axes 1 and 3 did not provide additional information that wasn't apparent from Figure 7, so the graph is not shown. They also found that native species were able to compete equally well with L. maackii growing in bottomland areas.

The results of the randomization test reported a $\mathrm{P}$-value for axis 1 only $(\mathrm{P}=0.001$, both communities), and stated that P-values were not reported for axes 2 and 3 because randomization tests for these axes may bias the P-values. I believe this is due to the fact 
that the environmental variables explained so little variation in the first place, or because the species-by-site matrix contained too many empty cells, and type II errors may be more likely to occur. As such, the P-value for axis 1 may be biased, and the significance of this value should be interpreted cautiously. 


\section{DISCUSSION}

For many reasons, including planting of non-native horticultural varieties by residents nearby or via past management decisions, large city parks have become colonized by a host of non-native plant species, some of which cause serious problems for native plant regeneration over time (DeCandido 2004; Vidra et al. 2006; Kowarik 2011; Nielsen et al. 2014). Removing these dominant invasive plants can quickly drain the budgets of park management agencies if restoring the native plant community is a goal. By writing grants and with the help of passionate, motivated volunteers and community-wide fund-raising events throughout the year, the LOPC has been able to hire trained staff to clear the woodlands of dominant invasive plants that visibly stifle plant diversity and tree regeneration in the park. Important invasives targeted for removal in Cherokee Park were shrub honeysuckle (primarily Lonicera maackii) and woody vines (mostly exotics, but also the native, Vitis sp.) that shrouded trees in many locations across the park, especially along woodland edges. The need to evaluate the success of this invasive species eradication program prompted the LOPC to establish many long-term plots and transects across this park's wooded areas. The transects used in this study represent a subset of these plots that were established in 2007 at the start of the eradication program to evaluate the extent to which removals would benefit the very invasives removed. In 2014, the decision was made to quantify not only the original 11 invasive species but all plant species in the community, and thus provide a baseline for 
future evaluation of changes in the park.

The decision to establish transects for tracking the spread of the invasives after removal is justified because removal of dense thickets of Lonicera shrubs and vine shrouds would alter abiotic and biotic variables that are known to promote colonization, germination and growth of many plant species, including the invasives themselves. Primary among these would be increased light and greater inputs of seed rain from outside the woodland patches. Also, removal of dense shrub thickets would allow people and animals greater access to these areas, resulting in import of animal-vectored seeds as well as those that are wind and water-vectored. Invasive plants would be expected to respond to increases in these factors as well as many native plants. And indeed, seven years after the removal program began, most of the targeted 11 invasives, especially the shade tolerant woody vines, appear to have benefitted from this management disturbance by becoming more widespread. Compared with 2007, there are now nearly 2 invasive species $\mathrm{m}^{-2}$ of woodland in Cherokee Park rather than $1.6 \mathrm{~m}^{-2}$. However, the percentage of quadrats that contain at least one invasive species increased by just $1 \%$ in 2014 , indicating that the ratio of invaded to non-invaded areas did not appear to change substantially. Instead, the species density of invasive plants has increased in response to the removal efforts, with new invasives arriving in quadrats that had already been invaded by others. This increase in mean invasive species density was due primarily to the highly significant increases in A. petiolata and E. fortuneii, which are now the most widespread invasive species in Cherokee Park.

The coefficient of dispersion may provide some ecological insight into the ability of key invasives to dominate a site. Firstly, the calculated dispersion values being less 
than one imply that the park-wide distribution of invasive species was not random, but uniform. This type of distribution is also known as repulsed, regular, or uniform, which Sokal and Rohlf (1995) explain may be the result of one event that impedes the occurrence of a second event. In our case, this could result when the presence of one invasive species in a quadrat impedes the success of a second invasive species nearby. Repulsion is not normally observed in ecological settings (Grieg-Smith 1964; Duncan 1972), although Grieg-Smith notes that repulsed distributions can occur when the density of a given species is very high and approaching its maximum potential density. Where this happens, plants may physically occupy most, if not all, of the available above-ground and below-ground space, and prevent other species from occupying the same space. The woody vines, H. helix and E. fortuneii, often form dense mats on the ground before climbing shrubs and trees, and in this study, quadrats containing these two species had the fewest number of other species co-existing with them. Thus, they may impede not only the growth of existing vegetation, but also seed germination, resulting in large monocultures of ground cover (Miller 2006; Biggerstaff and Beck 2007; Zouhar 2009).

The lower coefficient of dispersion in 2007 relative to 2014 may be explained by the fact that most of the park had been under invasion for decades, at least since the tornado of 1974, resulting perhaps in an "invasive climax community" of 1 or 2 species per $\mathrm{m} 2$ as the tree canopy was restored over time. In contrast, the abrupt removal of invasive plant biomass, coupled with increased sunlight, may have eliminated the impedance to colonization by other invasives, resulting in an increase in mean invasive species density, and consequently, a less repulsed distribution. These results mean that management should be prepared to locate and eradicate new invasive individuals, 
particularly in higher quality woodland areas, after widespread removal of invasive shrub and vine biomass in the park.

\section{The New Threat? Alliaria petiolata}

In 2014, A. petiolata was detected in more quadrats than any other species in the park, invasive or otherwise, and also exhibited the largest increase in frequency since 2007. Since it has the potential to reduce native plant diversity (Rodgers et al. 2008), this dramatic increase in distribution could threaten the restoration of the native plant community in the Cherokee Park woodlands. Many characteristics make this plant a successful invader of woodland areas, such as the production of allelopathic compounds, tolerance to shade and disturbances, high reproductive output, and early phenology (Rodgers et al. 2008). Evidence also suggests that seed output in A. petiolata increases as light intensity increases (Phillips-Mao et al. 2014), leading to greater dispersal ability as well. If we assume that the removal of invasive shrubs and vines increased the amount of light available to the understory, this could explain why A. petiolata became more widespread in the 7 years since initial frequency data were collected.

Much of the research on A. petiolata has focused on its production of allelopathic compounds, which are associated with decreases in diversity and biomass of arbuscular mycorrhizal fungi (Stinson et al. 2006; Bauer et al. 2012). Also known as AMF, these fungi colonize the roots of most woodland herbs and trees, forming a mutualistic association that is necessary for their growth and survival (Stinson et al. 2006). Even after A. petiolata has been removed from an area, these compounds may persist in the soil and continue to disrupt the mutualism between AMF and native plant species (Prati and 
Bossdorf 2004; Stinson et al. 2006; Rodgers et al. 2008). This mechanism may be partially responsible for the decline in native plant abundance and diversity in areas that it has invaded (Prati and Bossdorf 2004). Callaway and Ridenour (2004) have called these allelopathic chemicals a "novel weapon," since native species neither produce them nor have ever encountered them. Based on this hypothesis, novel weapons can lead to increased competitive ability against native plant species, ultimately contributing to success of the invasive. Such belowground effects help explain the persistence of $A$. petiolata in many natural areas, despite ongoing efforts to control it. This may partly be explained by the fact that as a member of the Brassicaceae, A. petiolata does not depend on AMF root infection for successful growth (Stinson et al. 2006; Phillips-Mao et al. 2014).

\section{Woody Vines Continue To Increase}

Invasive woody vines can pose one of the biggest threats to long-term regeneration of forests and woodlands, and should be an important focus of any longterm management plan (Webster et al. 2006). They can disrupt forest regeneration by strangling saplings and inhibiting seedling germination (Miller 2006; Biggerstaff and Beck 2007), suppressing the reproduction of native herbs (Pyle 1995), and damaging the canopies of shrubs and trees (Pyle 1995). The three woody vine species that exhibited significant increases in abundance in Cherokee Park from 2007 to 2014 (E. fortuneii, L. japonica, and $H$. helix) have had over 120 years to exert these damaging effects on the woodlands, and are likely to be a problem for years to come. 
Aside from being planted as part of the park's original landscaping in 1891 (Carreiro and Zipperer 2011), these three species share similar characteristics that may explain why they have become successful invaders of this woodland. For example, they are shade tolerant, produce seeds that are eaten and dispersed by birds, and can inhibit the growth of native vegetation by smothering or blocking access to sunlight (Munger 2002; Zouhar 2009; Waggy 2010). Furthermore, being evergreen or nearly so, these vines can capture sunlight for photosynthesis while most of the native vegetation is without leaves, then reduce native species' access to light by shading in the spring.

Ordination found that the evergreen species $E$. fortuneii and $H$. helix were both associated with woodland areas that were far from disturbances and had high canopy cover, with canopy cover being most associated with the presence of Acer saccharum. These results are supported by previous studies and information on the distributions of these two invasive vines. In particular, they are known to avoid wet areas, as they do not grow well in wet soil (Miller 2006; Swearingen et al. 2010; USDA, NRCS 2015). But along urban creeks like Beargrass Creek, rain events often cause intense but short-lasting floods, and the anaerobic conditions associated with more natural riparian settings do not develop. Proximity to the flood zone may not represent a disturbance after all, but a condition that plants have adapted to, and may be one reason why E. fortunei has become so prevalent. Also, in the midwestern United States they tend to be more invasive in deciduous forests where Acer spp. is the dominant canopy tree (Zouhar 2009; Waggy 2010). This is corroborated by the analysis of the 2014 community, which showed Acer saccharum to be the most commonly occurring tree, while Acer negundo was the third most common. 
While not a true evergreen, L. japonica is known to keep its leaves well into the winter months, and often produces new leaves by mid-March, before many other native deciduous species (Munger 2002). In addition to getting an early start for photosynthesis, this would also have a shading effect on native vegetation that produces leaves after $L$. japonica, further increasing this vine's competitiveness (Pyle 1995; Munger 2002). L. japonica is known to benefit from an increase in understory light availability due to canopy disturbances, with greatest biomass occurring in areas where small diameter vegetation (i.e. herbs, saplings, shurbs) is also present (Munger 2002). These conditions persisted for at least two years following 1974 tornado, and probably to a lesser extent during the invasive shrub and vine removals, which potentially explains the decades of success L. japonica has had.

\section{Unexplained Decline: Glechoma hederacea}

As an herbaceous vine, G. hederaceae is incapable of the vertical growth that often damages native shrubs and trees, but it can still form dense monocultures on the ground that displace native vegetation (Waggy 2009; Swearingen et al. 2010). The reasons for the detected decline of this species in Cherokee Park woodlands are not immediately apparent, since it seems to be an effective invader across the range of environmental conditions that were measured at this study site (Waggy 2009). If the removal of invasive shrubs and vines did in fact increase light availability throughout the park, its decline may be the result of an inability to tolerate higher light conditions (Pyle 1995). Alternatively, growth of other species released by the increased sunlight may have displaced $G$. hederaceae. For example, ordination indicated weak associations between 
G. hederaceae and L. japonica, as well as two native herb taxa (Ageratina altissima and Impatiens spp.) that are common generalists in disturbed woodlands of this region (Luken et al. 1997; Davis et al. 2012). While this suggests that they were able to co-exist in 2014, this co-existence only represents a snapshot in time, and future studies will be needed to see how these four species are actually changing over time. Biocontrol could also be a potential explanation. In 2000, a rust fungus was identified growing on two G. hederacea specimens (Scholler 2000), one in New York, the other in central Indiana. It is possible that this fungus is widely distributed, and that it arrived in Cherokee Park sometime within the past 15 years. Future studies should consider its presence as a possibility in areas that have been colonized by $G$. hederacea.

\section{Lonicera maackii}

The removal of densely growing invasive shrubs like $L$. maackii is often the first step in any restoration plan, since the reduction in canopy cover, and hence the increase in sunlight near the forest floor, is needed to stimulate native herb and tree seed germination and seedling growth (Shields et al. 2015). Studies that have examined plant community responses after $L$. maackii removal found that these sites still contained the exotic shrub as seedlings, but that species richness, abundance, and density of native species all increased significantly in the first few years (Shields et al. 2015). This seems to be consistent with what has been observed in Cherokee Park (Carreiro 2014) and is an indication that management and restoration is succeeding in increasing native species richness.

On the other hand, studies have also found that A. petiolata (Luken et al. 1997; Shields et al. 2015) abundance tends to increase immediately following removal of $L$. 
maackii. Luken et al. (1997) also note that disturbance due to management may encourage a wide range of species to invade. Proper monitoring and periodic removals are still recommended, since Gorchov et al. (2014) found that individuals reach reproductive age by 4-5 years, producing fruits that are easily dispersed by birds, whitetailed deer, and mice. The park is surrounded by many landscaped yards and degraded woodlots that contain various ornamental exotic and invasive species, including $L$. maackii. In addition, part of Interstate 64 runs right alongside the northern boundary of the park and is lined with L. maackii, serving as a constant source of propagules into the park.

\section{Plant Community}

In 2014, the transects established in 2007 for tracking the 11 targeted invasives were also used to obtain a snapshot of the status and distribution of native and other nonnative species in the park woodlands. These data can provide a baseline for tracking future changes in these important components of the plant community as well. The Coefficient of Conservatism Value (CV) for Kentucky was assigned to all native species, and was used to identify potential species and areas of conservation interest, as well as to describe the overall quality of the woodlands. Co-occurrences between native and nonnative/invasive species were evaluated to determine whether native species, especially those with high conservation values, could co-exist with the invasive species being targeted for removal. Species richness, number of taxa within each growth habit, and total number of families, for native and non-native/invasive species, were calculated and compared with previous studies in the literature. In terms of growth habit, I found that 
herbs are the most frequent habit by far, which is in agreement with much of the literature (Pyle 1995; Luken et al. 1997; Phillips-Mao et al. 2014; Shields et al. 2015). However, I found that native taxon richness was twice as high as exotic taxon richness, which conflicts with other studies that have reported higher exotic species richness than native species richness, especially in urban parks (Nielsen et al. 2014), or in different ratios of native vs. exotic species (Drayton and Primack 1996; DeCandido 2004).

As management and restoration continue, the change in quality of various woodland habitats can now be monitored for change by using the CV scores and observing the species that colonize the area. However, it is important to consider that there are likely many differences between the pre-urbanized forest and the urban forest remnant that exists today (Hobbs et al. 2006; Simberloff 2010; Morse et al. 2014. In fact, this may be true for all urban areas in general, where the increasing propagule pressure of exotic species has overwhelmed historic species assemblages, and irreversibly transformed the natural ecosystem into what has been called a novel ecosystem (Hobbs et al. 2006; Simberloff 2010).

Many definitions of novel ecosystems exist, but Morse et al. (2014) give four criteria that must be met for an ecosystem to be defined as "novel." First, human action within the geographic location of the ecosystem must have directly altered the ecosystem. Second, some threshold must be passed whereby the ecosystem is irreversibly changed from its previous state, which can include the introduction of invasive species. Third, a new species composition must arise that has not been seen in other ecosystems within the biome, which can happen if invasive species outcompete native species and alter 
community structure. And finally, they must be able to persist without continued human intervention, such as management practices.

Unfortunately, humans often alter the ecosystems in which they reside, either intentionally by accident, but this is especially apparent in urban areas (Hulme 2009; Kowarik 2011) like Louisville, Kentucky. For example, the discharge of wastewater into Beargrass Creek has altered the nutrient cycle and polluted the waterway, and over the course of many years, has likely turned Cherokee Park into what Morse et al. (2014) call an impacted ecosystem. Importantly though, they state that the threshold has yet to be crossed, implying that removal of any unintentional alterations could allow a resilient system to return to normal. But the authors then contradict this previous statement by saying that the introduction of non-native species, which are numerous in the park, are a common example of thresholds being crossed. This is especially evident in a plant like $L$. maackii which produce berries that are eaten by the park's fauna and then distribute them a good distance from the parent plant. (Gorchov et al. 2014) With respect to the third criterion, the species composition of Cherokee Park is not new, in fact it is rather common all throughout the Midwest, with many of the same key invasives found in woodlands across the region (USDA, NRCS 2015). But the fourth criterion, that novel ecosystems must be able to persist without continued intervention, is unlikely to be met. Management of the park's woodlands has been a priority of the LOPC since it formed, and efforts to eradicate invasive plant species and restore the native diversity in the woodlands are ongoing, and with positive results for native plants.

The plant community of Cherokee Park in 2014 was found to have over twice as many native species ( 85 species; 84 taxa used) as it did non-native and invasive taxa (39 
taxa). Again, this offers a contrast to the higher exotic species richness that is usually reported in the literature, or associated with urban areas in general (DeCandido 2004; Maskell et al 2006). Within parks, the higher exotic species richness is usually attributed to horticultural varieties (Cornelis and Hermy 2004), such as those found in arboreta or botanical gardens. The absence of those in Cherokee Park may be one explanation for the high native to non-native ratio found in the park, although some of these horticultural varieties (e.g., L. japonica and E. fortunei) were initially planted in the park (Kowarik 2011; Nielsen et al 2014). Nielsen et al. (2014) provides a synthesis of results from studies done on species richness in urban parks. In the seven studies dealing with the flora of urban parks, he found that exotic species, on average, accounted for $41.8 \%$ of woody species, and $42.6 \%$ of all plant species. These results are slightly higher than the $32.8 \%$ of woody species and $31.5 \%$ of all plant taxa that were recorded in this study. The importance of future studies, especially ones that measure abundance, will allow managers to see if these co-occurrences will turn into co-existences with non-natives in more or less permanently novel communities.

\section{Conservation Value of Species and Habitats}

Allium burdickii was found to have the highest CV score (8) in this study. It was found only once, and was surrounded by a small population of other conspecific individuals. Near this population were large groundcovers of E. fortunei, and A. quinata, as well as the non-native vine Vinca minor, and meter high stems of L. maackii, all of which may pose a threat to the survival of this population (Cipollini et al 2008). Indeed, Miller and Gorchov (2004) found that L. maackii individuals reduced the proportion of $A$. 
burdickii flowering individuals, as well as seed/fruit production per individual. Given that this population was rather small, rapid management and protection of this area will likely be needed to conserve this and other species of high value.

The overall quality of habitat, as determined by the mean $\mathrm{CV}$ of native species, can be considered degraded but somewhat stable, with taxa that can persist in a broad range of habitats under moderate habitat alteration; however, these will decline if alteration is long-lasting, intense, or frequent (Andreas et al. 2004). Examining the number of taxa within each $\mathrm{CV}$ category reveals an interesting distribution: there are nearly the same number of taxa with $\mathrm{CV}=5(15$ taxa) as there are with $\mathrm{CV}=2(17$ taxa). Plus, $37.5 \%$ of all native species have a $\mathrm{CV} \geq 5$, suggesting that within Cherokee Park, there are areas of suitable habitat for sensitive native species which would otherwise be unable to survive, and further emphasizes the need for protection of various habitat types.

Considering only those native species with a $\mathrm{CV} \geq 5$ that occurred in at least 10 quadrats, there are 11 taxa, comprised of the ferns, 5 spring ephemeral herbs, 1 shrub, and 4 trees. These were present in many areas of the park, not concentrated in one high quality area, which is a further indication that high quality areas of the park may be fairly well distributed. Examining these quadrats for co-occurrences with the five invasive species that exhibited significant changes in frequency, I found that $E$. fortunei was the only one to have occurred at least once with each of the 11 taxa, while L. japonica occurred with all but one herb. For the 6 herb taxa with high CV scores, the percent of quadrats in which any of the top 4 invasives occurred ranged from a low of $29 \%$ for ferns to $43 \%$ for $A$. canadense. For management purposes, this could be good news- that these high quality species may be able to co-exist with the most widespread invasives, and 
management could be kept to a minimum to avoid potentially harmful disturbances. But this could also be a sign that the invasives are threatening them right now and there needs to be intervention or these populations may get displaced, particularly the spring ephemerals since they were not as frequent to begin with.

Management efforts to control and remove invasive species so far seem to be a success, if measured by the number of native species that can co-exist and the quality of the habitat. Invasive species density has actually increased since 2007 , but that does not indicate failure, or that we may be trying to change a novel ecosystem that has passed an irreversible threshold. Now that baseline data has been established for the native plant community, comparisons after any future large-scale management projects can be made to assess the impact that they have on the community or ecosystem as a whole. Changes in habitat quality, species richness, and species composition can be tracked and used to gauge community responses to new species introductions, disturbances, or restoration projects. It is recommended that future projects should include more quadrats in the disturbed areas, and in a more even design. Pyle (1995) examined the effects of flooding and forest fragmentation on exotic species richness and found effects of both. Thus, it is possible that one or more of the disturbances within the park may be influencing the distribution of invasive species but cannot be detected due to low representation of quadrats in these areas. Ordination suggests in particular that Ampelopsis brevipedunculata is associated with open canopy and proximity to mow zones, so identifying whether this was a result of small sample size or a real effect has important implications for managers. 
In addition to the results of previous work performed by Carreiro (2014) in Cherokee Park, this study indicates that native species, and especially those that are rare or sensitive to anthropogenic disturbances, have made a comeback. Unfortunately, so have many of the invasive plant species that were targeted for removal and control with the initiation of this study, prior to the 2014 community assessment. This resurgence of invasives should not take away from the progress made by the LOPC so far, but it does highlight the need for ongoing monitoring and the frequent removal of problematic species that will likely follow. Complete eradication in the face of constant pressure from invasive species beyond the park's boundary is most likely an unrealistic goal. However, with continued projects aimed at removing harmful species from priority areas, such as those with quality habitat or important native species, the native diversity that does exist can be maintained. If these species begin to thrive and valuable habitat areas preserve the current biodiversity within the park, areas with heavy invasions could potentially be reduced (Levine and D'Antonio 1999). This would potentially relieve some of the burden that invasive species management places on the LOPC, and allow them to focus on other projects within the park. The work of the LOPC thus ensures that Cherokee Park and its future visitors will benefit from the access to nature that this woodland provides for years to come. 


\section{REFERENCES}

Allendorf, F. W., \& Lundquist, L. L. (2003). Introduction: population biology, evolution, and control of invasive species. Conservation Biology, 17(1), 24-30.

Alvey, A. A. (2006). Promoting and preserving biodiversity in the urban forest. Urban Forestry \& Urban Greening, 5(4), 195-201.

Andreas, B. K., Mack, J. J., \& McCormac, J. S. (2004). Floristic Quality Assessment Index (FQAI) for vascular plants and mosses for the State of Ohio: Ohio EPA.

Bauer, J. T., Shannon, S. M., Stoops, R. E., \& Reynolds, H. L. (2012). Context dependency of the allelopathic effects of Lonicera maackii on seed germination. Plant Ecology, 213(12), 1907-1916.

Beck, K. G., Zimmerman, K., Schardt, J. D., Stone, J., Lukens, R. R., Reichard, S., . . Thompson, J. P. (2008). Invasive species defined in a policy context: Recommendations from the Federal Invasive Species Advisory Committee. Invasive Plant Science and Management, 1(4), 414-421.

Benjamini, Y., \& Hochberg, Y. (1995). Controlling the false discovery rate: a practical and powerful approach to multiple testing. Journal of the Royal Statistical Society. Series B (Methodological), 289-300. 
Biggerstaff, M. S., \& Beck, C. W. (2007). Effects of English ivy (Hedera helix) on seed bank formation and germination. The American midland naturalist, 157(2), 250-257.

Callaway, R. M., \& Ridenour, W. M. (2004). Novel weapons: invasive success and the evolution of increased competitive ability. Frontiers in Ecology and the Environment, 2(8), 436-443.

Cantlon, J. E. (1953). Vegetation and microclimates on north and south slopes of Cushetunk Mountain, New Jersey. Ecological Monographs, 241-270.

Carreiro, M. M., \& Zipperer, W. C. (2011). Co-adapting societal and ecological interactions following large disturbances in urban park woodlands. Austral Ecology, 36(8), 904-915.

Carreiro, M. M. 2014. UrbanWoodlands Soil Erosion Reduction Study. Final Report to the Environmental Protection Agency and the Louisville Olmsted Parks Conservancy. $160 \mathrm{pp}$.

Cipollini, K. A., McClain, G. Y., \& Cipollini, D. (2008). Separating above-and belowground effects of Alliaria petiolata and Lonicera maackii on the performance of Impatiens capensis. The American midland naturalist, 160(1), 117-128.

Cornelis, J., \& Hermy, M. (2004). Biodiversity relationships in urban and suburban parks in Flanders. Landscape and Urban Planning, 69(4), 385-401.

Davis, M. A., Colehour, A., Daney, J., Foster, E., Macmillen, C., Merrill, E., .. . Anderson, M. D. (2012). The population dynamics and ecological effects of garlic 
mustard, Alliaria petiolata, in a Minnesota oak woodland. The American midland naturalist, 168(2), 364-374.

DeCandido, R. (2004). Recent changes in plant species diversity in urban Pelham Bay Park, 1947-1998. Biological Conservation, 120(1), 129-136.

Drayton, B., \& Primack, R. B. (1996). Plant species lost in an isolated conservation area in metropolitan Boston from 1894 to 1993. Conservation Biology, 10(1), 30-39.

Evangelista, P. H., Kumar, S., Stohlgren, T. J., Jarnevich, C. S., Crall, A. W., Norman III, J. B., \& Barnett, D. T. (2008). Modelling invasion for a habitat generalist and a specialist plant species. Diversity and Distributions, 14(5), 808-817.

Gayek, A., \& Quigley, M. F. (2001). Does topography affect the colonization of Lonicera maackii and Ligustrum vulgare in a forested glen in southwestern Ohio? The Ohio Journal of Science, 101(5), 95-100

Golivets, M. (2014). Ecological and biological determination of invasion success of nonnative plant species in urban woodlands with special regard to short-lived monocarps. Urban Ecosystems, 17(1), 291-303.

Gorchov, D. L., Castellano, S. M., \& Noe, D. A. (2014). Long-distance dispersal and diffusion in the invasion of Lonicera maackii. Invasive Plant Science and Management, 7(3), 464-472.

Greig-Smith, P. (1964). Quantitative Plant Ecology: Butterworths. 
Haragan, P. D. (2014). The Olmsted parks of Louisville : a botanical field guide.

Lexington, Kentucky: The University Press of Kentucky.

Herbaria, M. S., Herbaria, A., \& Herbaria, K. (2000). Rust on ground-ivy found for the first time in North America. Plant Disease, 84(3), 371-371.

Hobbs, R. J., Arico, S., Aronson, J., Baron, J. S., Bridgewater, P., Cramer, V. A., . . . Lugo, A. E. (2006). Novel ecosystems: theoretical and management aspects of the new ecological world order. Global ecology and biogeography, 15(1), 1-7.

Holland, P., \& Steyn, D. (1975). Vegetational responses to latitudinal variations in slope angle and aspect. Journal of Biogeography, 179-183.

Huebner, C. D., Nowak, D. J., Pouyat, R. V., \& Bodine, A. R. (2012). Nonnative invasive plants: Maintaining biotic and socioeconomic integrity along the urban-rural-natural area gradient. Urban-Rural Interfaces: Linking People and Nature(urbanruralinter), 71-98.

Hulme, P. E. (2009). Trade, transport and trouble: managing invasive species pathways in an era of globalization. Journal of Applied Ecology, 46(1), 10-18.

Jones, H. G. (2013). Plants and microclimate: a quantitative approach to environmental plant physiology: Cambridge university press.

Kowarik, I. (2011). Novel urban ecosystems, biodiversity, and conservation. Environmental Pollution, 159(8), 1974-1983.

Lemmon, P. E. (1956). A spherical densiometer for estimating forest overstory density. Forest Science, 2(4), 314-320. 
Levine, J. M., \& D'Antonio, C. M. (1999). Elton revisited: a review of evidence linking diversity and invasibility. Oikos, 15-26.

Luken, J., Kuddes, L., \& Tholemeier, T. (1997). Response of Understory Species to Gap Formation and Soil Disturbance m Lonicera maackii Thickets. Restoration Ecology, 5(3), 229-235.

Maskell, L., Bullock, J., Smart, S., Thompson, K., \& Hulme, P. (2006). The distribution and habitat associations of non-native plant species in urban riparian habitats. Journal of Vegetation Science, 17(4), 499-508.

McCune, B., Grace, J. B., \& Urban, D. L. (2002). Analysis of ecological communities (Vol. 28): MjM software design Gleneden Beach, OR.

Miller, J. H. (2006). Nonnative invasive plants of southern forests. USDA Forest Service/UNL Faculty Publications, 103.

Morse, N. B., Pellissier, P. A., Cianciola, E. N., Brereton, R. L., Sullivan, M. M., Shonka, N. K., . . McDowell, W. H. (2014). Novel ecosystems in the Anthropocene: a revision of the novel ecosystem concept for pragmatic applications. Ecol. Soc, 19(2).

Nielsen, A. B., van den Bosch, M., Maruthaveeran, S., \& van den Bosch, C. K. (2014). Species richness in urban parks and its drivers: a review of empirical evidence. Urban Ecosystems, 17(1), 305-327.

Peck, J. E. (2010). Multivariate analysis for community ecologists: MjM Software Design. 
Phillips-Mao, L., Larson, D. L., \& Jordan, N. R. (2014). Effects of Native Herbs and Light on Garlic Mustard (Alliaria petiolata) Invasion. Invasive Plant Science and Management, 7(2), 257-268.

Pimentel, D., Zuniga, R., \& Morrison, D. (2005). Update on the environmental and economic costs associated with alien-invasive species in the United States. Ecological Economics, 52(3), 273-288.

Pipal, R. P. (2014) Earthworm, microbial biomass, and leaf litter decay responses after invasive honeysuckle shrub removal from urban woodlands. Electronic Theses and Dissertations. Paper 1759.

Prati, D., \& Bossdorf, O. (2004). Allelopathic inhibition of germination by Alliaria petiolata (Brassicaceae). American Journal of Botany, 91(2), 285-288.

Pyle, L. L. (1995). Effects of disturbance on herbaceous exotic plant species on the floodplain of the Potomac River. American Midland Naturalist, 244-253.

Roberts, D. W. (1986). Ordination on the basis of fuzzy set theory. Vegetatio, 66(3), 123 131.

Rodgers, V. L., Stinson, K. A., \& Finzi, A. C. (2008). Ready or not, garlic mustard is moving in: Alliaria petiolata as a member of eastern North American forests. BioScience, $58(5), 426-436$.

Ruxton, G. D. (2006). The unequal variance t-test is an underused alternative to Student's t-test and the Mann-Whitney U test. Behavioral Ecology, 17(4), 688-690. 
Shea, M., D. White, M. Evans, and D.M. Ladd. No date. Kentucky coefficients of conservatism. Unpublished data. Available online at http://www.dropseednursery.com/resources/plantlist/

Shields, J. M., Saunders, M. R., Gibson, K. D., Zollner, P. A., Dunning, J. B., \& Jenkins, M. A. (2015). Short-Term Response of Native Flora to the Removal of Non-Native Shrubs in Mixed-Hardwood Forests of Indiana, USA. Forests, 6(6), 1878-1896.

Simberloff, D. (2010). Invasions of plant communities-More of the same, something very different, or both? The American midland naturalist, 163(1), 220-233.

Smith, J. (1977). Vegetation and microclimate of east-and west-facing slopes in the grasslands of Mt Wilhelm, Papua New Guinea. The Journal of Ecology, 39-53.

Sokal, R. R., \& Rohlf, F. J. (1995). Biometry: the principles andpractice of statistics in biological research. WH. Freeman\& Co., San Francisco. SokalBiometry: the principles and practice of statistics in biological research1995.

Stinson, K., Kaufman, S., Durbin, L., \& Lowenstein, F. (2007). Impacts of garlic mustard invasion on a forest understory community. Northeastern Naturalist, 14(1), 73-88.

Stinson, K. A., Campbell, S. A., Powell, J. R., Wolfe, B. E., Callaway, R. M., Thelen, G. C., . . Klironomos, J. N. (2006). Invasive plant suppresses the growth of native tree seedlings by disrupting belowground mutualisms. PLoS biology, 4(5), 727. 
Swearingen, J., Slattery, B., Reshetiloff, K., \& Zwicker, S. (2010) Plant Invaders of MidAtlantic Natural Areas, 4th ed. National Park Service and U.S. Fish and Wildlife Service. Washington, DC. 168pp.

Swink, F., \& Wilhelm, G. (1994). Plants of the Chicago region, $4^{\text {th }}$ Edition. Indiana Academy of Science, Lisle, IL.

Trammell, T. L., \& Carreiro, M. M. (2011). Vegetation composition and structure of woody plant communities along urban interstate corridors in Louisville, KY, USA. Urban Ecosystems, 14(4), 501-524.

U. S. Census Bureau (2010) http://quickfacts.census.gov/qfd/states/21/21111.html

USDA, NRCS. 2015. The PLANTS Database (http://plants.usda.gov, June-November 2015). National Plant Data Team, Greensboro, NC 27401-4901 USA.

Vidra, R. L., Shear, T. H., \& Wentworth, T. R. (2006). Testing the paradigms of exotic species invasion in urban riparian forests. Natural Areas Journal, 26(4), 339-350.

Waggy, Melissa A. 2009. Glechoma hederacea. In: Fire Effects Information System, [Online]. U.S. Department of Agriculture, Forest Service, Rocky Mountain Research Station, Fire Sciences Laboratory (Producer). Available: http://www.fs.fed.us/database/feis/ [2015, November]. 
Waggy, Melissa A. 2010. Hedera helix. In: Fire Effects Information System, [Online].

U.S. Department of Agriculture, Forest Service, Rocky Mountain Research Station, Fire Sciences Laboratory (Producer). Available: http://www.fs.fed.us/database/feis/ [2015, November].

Walker, B., \& Steffen, W. (1997). An overview of the implications of global change for natural and managed terrestrial ecosystems. Conservation Ecology, 1(2), 2.

Webster, C. R., Jenkins, M. A., \& Jose, S. (2006). Woody invaders and the challenges they pose to forest ecosystems in the eastern United States. Journal of Forestry, 104(7), 366-374.

Wilcove, D. S., Rothstein, D., Dubow, J., Phillips, A., \& Losos, E. (1998). Quantifying threats to imperiled species in the United States. BioScience, 607-615.

Zouhar, Kris. 2009. Euonymus fortunei. In: Fire Effects Information System, [Online]. U.S. Department of Agriculture, Forest Service, Rocky Mountain Research Station, Fire Sciences Laboratory (Producer). Available: http://www.fs.fed.us/database/feis/ [2015, November]. 
Table 1. Invasive species targeted for management in Cherokee Park woodlands, and sorted by growth habit. Vitis sp. is native. All others are non-native.

\begin{tabular}{lc}
\hline Species & Habit \\
\hline Alliaria petiolata & Herb/Forb \\
Glechoma hederacea & Herbaceous vine \\
Lonicera maackii & Shrub \\
Ailanthus altissima & Tree \\
Akebia quinata & Woody vine \\
Ampelopsis sp. & Woody vine \\
Celastrus orbiculatus & Woody vine \\
Euonymus fortuneii & Woody vine \\
Hedera helix & Woody vine \\
Lonicera japonica & Woody vine \\
Vitis sp. & Woody vine \\
\hline
\end{tabular}


Table 2. Species frequencies and rankings for 2007 and 2014. Frequency is reported as number of quadrats where the species occurred; parentheses enclose percentage of total quadrats. Species are sorted alphabetically.

\begin{tabular}{lcccc}
\hline & \multicolumn{2}{c}{2007} & \multicolumn{2}{c}{2014} \\
\cline { 2 - 5 } Species & Rank & Frequency & Rank & Frequency \\
\hline Ailanthus altissima & 11 & $7(1.4)$ & 11 & $5(1)$ \\
Akebia quinata & 10 & $15(3)$ & 10 & $17(3.4)$ \\
Alliaria petiolata & 5 & $84(16.9)$ & 1 & $189(38)$ \\
Ampelopsis sp. & 7 & $42(8.5)$ & 8 & $46(9.3)$ \\
Celastrus orbiculatus & 9 & $31(6.2)$ & 9 & $27(5.4)$ \\
Euonymus fortuneii & 4 & $102(20.5)$ & 2 & $185(37.2)$ \\
Glechoma hederacea & 1 & $144(29)$ & 5 & $93(18.7)$ \\
Hedera helix & 8 & $39(7.8)$ & 7 & $63(12.7)$ \\
Lonicera japonica & 3 & $118(23.7)$ & 3 & $158(31.8)$ \\
Lonicera maackii & 6 & $83(16.7)$ & 6 & $87(17.5)$ \\
Vitis sp. & 2 & $129(26)$ & 4 & $117(23.5)$ \\
\hline
\end{tabular}


Table 3. Net change of invasive species frequency from 2007-2014 for the 9 species that were analyzed. Species are ranked from largest increase in presence to largest decrease in presence; a positive gain represents a net increase in presence, while a negative gain represents a net decrease in presence. Adjusted P-values are Benjamini-Hochberg corrected P-values.

\begin{tabular}{lcc}
\hline Rank Order & Gain & Adj. P-value \\
\hline Alliaria petiolata & 105 & $<0.001$ \\
Euonymus fortuneii & 83 & $<0.001$ \\
Lonicera japonica & 40 & 0.015 \\
Hedera helix & 24 & 0.014 \\
Ampelopsis brevipedunculata & 4 & 0.726 \\
Lonicera maackii & 4 & 0.76 \\
Akebia quinata & 2 & $\mathrm{~N} / \mathrm{A}$ \\
Ailanthus altissima & -2 & $\mathrm{~N} / \mathrm{A}$ \\
Celastrus orbiculatus & -4 & 0.726 \\
Vitis sp. & -12 & 0.625 \\
Glechoma hederacea & -51 & 0.001 \\
\hline
\end{tabular}


Table 4. Species in the 2014 plant community with a Coefficient of Conservatism Value $(\mathrm{CV})$ of 5 or greater, including growth habit and frequency of occurrence.

\begin{tabular}{|c|c|c|c|c|}
\hline Score & Species & Family & Habit & Frequency \\
\hline 8 & Allium burdickii & Liliaceae & Herb & 1 \\
\hline 7 & Aquilegia canadensis & Ranunculaceae & Tree & 46 \\
\hline 7 & Asimina triloba & Annonaceae & Tree & 32 \\
\hline 7 & Caulophyllum thalictroides & Berberidaceae & Herb & 14 \\
\hline 7 & Cystopteris tennesseensis & Dryopteridaceae & Shrub & 4 \\
\hline 7 & Fraxinus quadrangulata & Oleaceae & Herb & 1 \\
\hline 7 & Viburnum dentatum & Caprifoliaceae & Herb & 1 \\
\hline 6 & Acer nigrum & Aceraceae & Herb & 22 \\
\hline 6 & Arisaema triphyllum & Araceae & Herb & 14 \\
\hline 6 & Asarum canadense & Aristolochiaceae & Herb & 12 \\
\hline 6 & Bignonia capreolata & Bignoniaceae & Tree & 10 \\
\hline 6 & Gymnocladus dioicus & Caesalpiniaceae & Tree & 5 \\
\hline 6 & Ostrya virginiana & Betulaceae & Tree & 3 \\
\hline 6 & Podophyllum peltatum & Berberidaceae & Herb & 2 \\
\hline 6 & Quercus prinus & Fagaceae & Herb & 1 \\
\hline 6 & Quercus rubra & Fagaceae & Tree & 1 \\
\hline 6 & Solidago flexicaulis & Asteraceae & Tree & 1 \\
\hline 5 & Carya cordiformis & Juglandaceae & Herb & 26 \\
\hline 5 & Cornus florida & Cornaceae & Herb & 22 \\
\hline 5 & Elymus virginicus & Poaceae & Shrub & 15 \\
\hline 5 & Fagus grandifolia & Fagaceae & Tree & 11 \\
\hline 5 & Hydrophyllum appendiculatum & Hydrophyllaceae & Grass & 9 \\
\hline 5 & Hydrophyllum canadense & Hydrophyllaceae & Herb & 9 \\
\hline 5 & Ilex ораса & Aquifoliaceae & Herb & 8 \\
\hline 5 & Lindera benzoin & Lauraceae & Herb & 5 \\
\hline 5 & Maianthemum racemosum & Liliaceae & Tree & 4 \\
\hline 5 & Osmorhiza claytonii & Apiaceae & Tree & 3 \\
\hline 5 & Polygonatum biflorum & Liliaceae & Tree & 3 \\
\hline 5 & Quercus alba & Fagaceae & Tree & 3 \\
\hline 5 & Quercus muehlenbergii & Fagaceae & Herb & 3 \\
\hline 5 & Tilia americana & Tiliaceae & Tree & 2 \\
\hline 5 & Trillium sessile & Liliaceae & Tree & 1 \\
\hline
\end{tabular}


Table 5. Results of CCA performed on the Combined Community of 33 species showing the Axis Summary Statistics, and biplot scores used to create the biplot overlay. Biplot scores represent the coordinates of the red arrowhead associated with the environmental variable. Bolded values represent the 2 environmental variables that explained the most variation along a given axis.

Number of canonical axes: 3

Total variance ("inertia") in the species data: 4.3029

\begin{tabular}{|c|c|c|c|}
\hline & \multicolumn{3}{|c|}{ Axis Summary Statistics } \\
\hline & Axis 1 & Axis 2 & Axis 3 \\
\hline Eigenvalue & 0.136 & 0.065 & 0.056 \\
\hline \multicolumn{4}{|l|}{ Variance in species data } \\
\hline$\%$ of variance explained & 3.2 & 1.5 & 1.3 \\
\hline Cumulative \% explained & 3.2 & 4.7 & 6 \\
\hline \multicolumn{4}{|l|}{ Pearson Correlation, Spp- } \\
\hline Envt & 0.693 & 0.579 & 0.543 \\
\hline \multicolumn{4}{|l|}{ Kendall (Rank) Corr., Spp- } \\
\hline \multirow[t]{3}{*}{ Envt } & 0.499 & 0.382 & 0.354 \\
\hline & \multicolumn{3}{|c|}{ Biplot } \\
\hline & \multicolumn{3}{|c|}{ Scores } \\
\hline Variable & Axis 1 & Axis 2 & Axis 3 \\
\hline Eastness & -0.001 & 0.722 & -0.11 \\
\hline invRefCC & 0.645 & 0.401 & -0.029 \\
\hline SlopeDeg & 0.209 & 0.552 & -0.246 \\
\hline TrailDis & 0.397 & -0.51 & -0.704 \\
\hline FloodDis & 0.728 & -0.597 & 0.054 \\
\hline MowZnDis & 0.650 & -0.428 & -0.414 \\
\hline
\end{tabular}


Table 6. Results of CCA performed on the Combined Community of 33 species showing the Canonical Coefficients calculated for the environmental variables. The standardized canonical coefficients are used for graphing and for determining strength of association.

\begin{tabular}{ccccccccc} 
& \multicolumn{7}{c}{ Standardized } & \multicolumn{5}{c}{ Original Units } \\
\cline { 2 - 4 } \cline { 6 - 8 } Variable & Axis 1 & Axis 2 & Axis 3 & & Axis 1 & Axis 2 & Axis 3 & S.Dev \\
\hline Eastness & 0.057 & 0.534 & -0.067 & & 0.076 & 0.714 & -0.09 & $7.48 \mathrm{E}-01$ \\
invRefCC & 0.553 & 0.383 & -0.058 & & 3.782 & 2.621 & -0.395 & $1.46 \mathrm{E}-01$ \\
SlopeDeg & 0.299 & 0.295 & -0.048 & & 0.042 & 0.041 & -0.007 & $7.14 \mathrm{E}+00$ \\
TrailDis & -0.174 & -0.237 & -1.023 & & -0.001 & -0.002 & -0.008 & $1.22 \mathrm{E}+02$ \\
FloodDis & 0.749 & -0.311 & 1.059 & & 0.006 & -0.002 & 0.008 & $1.29 \mathrm{E}+02$ \\
MowZnDis & 0.162 & 0.019 & -0.488 & & 0.001 & 0 & -0.003 & $1.49 \mathrm{E}+02$ \\
\hline
\end{tabular}


Table 7. Results of CCA performed on the Invasive Community of 9 species showing the Axis Summary Statistics, and biplot scores used to create the biplot overlay. Biplot scores represent the coordinates of the red arrowhead associated with the environmental variable. Bolded values represent the 2 environmental variables that explained the most variation along a given axis.

Number of canonical axes: 3

Total variance ("inertia") in the species data: 2.0472

\begin{tabular}{|c|c|c|c|c|}
\hline & \multicolumn{4}{|c|}{$\begin{array}{c}\text { Axis Summary } \\
\text { Statistics }\end{array}$} \\
\hline & Axis 1 & Axis 2 & & Axis 3 \\
\hline Eigenvalue & 0.097 & & 0.04 & 0.032 \\
\hline \multicolumn{5}{|l|}{ Variance in species data } \\
\hline$\%$ of variance explained & 4.7 & & 2 & 1.6 \\
\hline Cumulative \% explained & 4.7 & & 6.7 & 8.2 \\
\hline Pearson Correlation, Spp-Envt & 0.547 & & 0.395 & 0.375 \\
\hline \multirow[t]{2}{*}{ Kendall (Rank) Corr., Spp-Envt } & 0.348 & & 0.235 & 0.262 \\
\hline & \multicolumn{4}{|c|}{ Biplot Scores } \\
\hline Variable & Axis 1 & Axis 2 & & Axis 3 \\
\hline Eastness & 0.053 & 0.660 & & 0.242 \\
\hline invRefCC & -0.605 & 0.408 & & -0.259 \\
\hline SlopeDeg & -0.159 & 0.38 & & 0.498 \\
\hline TrailDis & -0.459 & -0.674 & & 0.422 \\
\hline FloodDis & -0.55 & -0.613 & & -0.304 \\
\hline MowZnDis & -0.793 & -0.47 & & 0.153 \\
\hline
\end{tabular}


Table 8. Results of CCA performed on the Invasive Species Community (9 species) showing the Canonical Coefficients calculated for the environmental variables. The standardized canonical coefficients are used for graphing and for determining strength of association.

\begin{tabular}{|c|c|c|c|c|c|c|c|}
\hline \multirow[b]{3}{*}{ Variable } & \multicolumn{6}{|c|}{ Canonical Coefficients } & \\
\hline & \multicolumn{3}{|c|}{ Standardized } & \multicolumn{4}{|c|}{ Original Units } \\
\hline & Axis 1 & Axis 2 & Axis 3 & Axis 1 & Axis 2 & Axis 3 & S.Dev \\
\hline Eastness & 0.048 & 0.484 & 0.16 & 0.065 & 0.657 & 0.217 & 7.36E-01 \\
\hline invRefCC & -0.532 & 0.4 & -0.243 & -3.552 & 2.674 & -1.625 & $1.50 \mathrm{E}-01$ \\
\hline SlopeDeg & -0.143 & 0.149 & 0.313 & -0.02 & 0.021 & 0.045 & $7.00 \mathrm{E}+00$ \\
\hline TrailDis & 0.285 & -0.546 & 0.893 & 0.002 & -0.004 & 0.007 & $1.29 E+02$ \\
\hline FloodDis & 0.115 & -0.343 & -1.034 & 0.001 & -0.003 & -0.008 & $1.33 \mathrm{E}+02$ \\
\hline MowZnDis & -1.068 & 0.251 & 0.334 & -0.007 & 0.002 & 0.002 & $1.56 \mathrm{E}+02$ \\
\hline
\end{tabular}




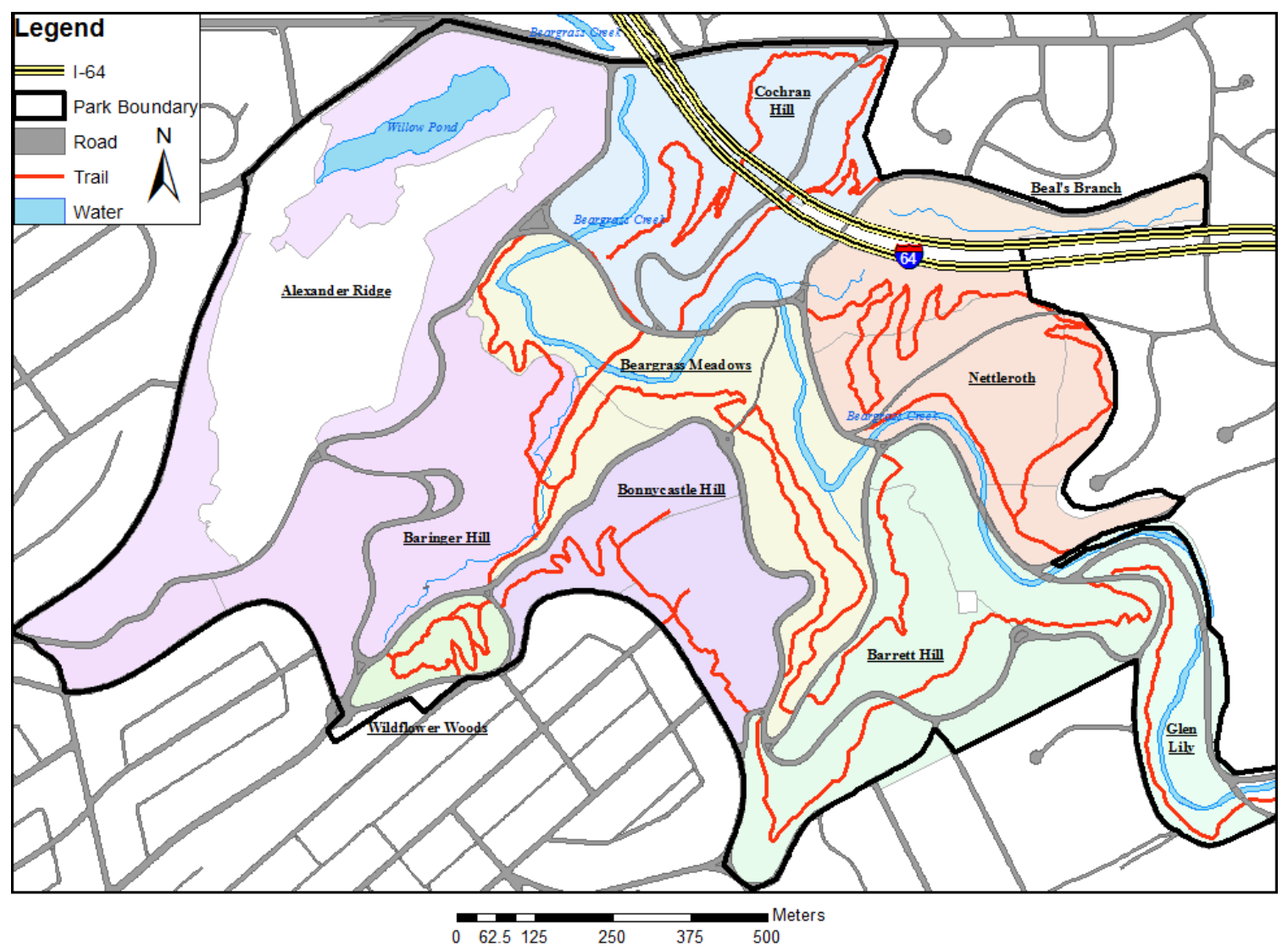

Figure 1. The ten Cherokee Park management areas. The 166 ha park, which includes the 78 ha woodlands that this study was conducted in, is surrounded by residential land use. Beargrass Creek meanders through the park, while interstate highway 64 runs through a tunnel below the park. Pastel colors were used to make the boundaries of management areas more visible. 


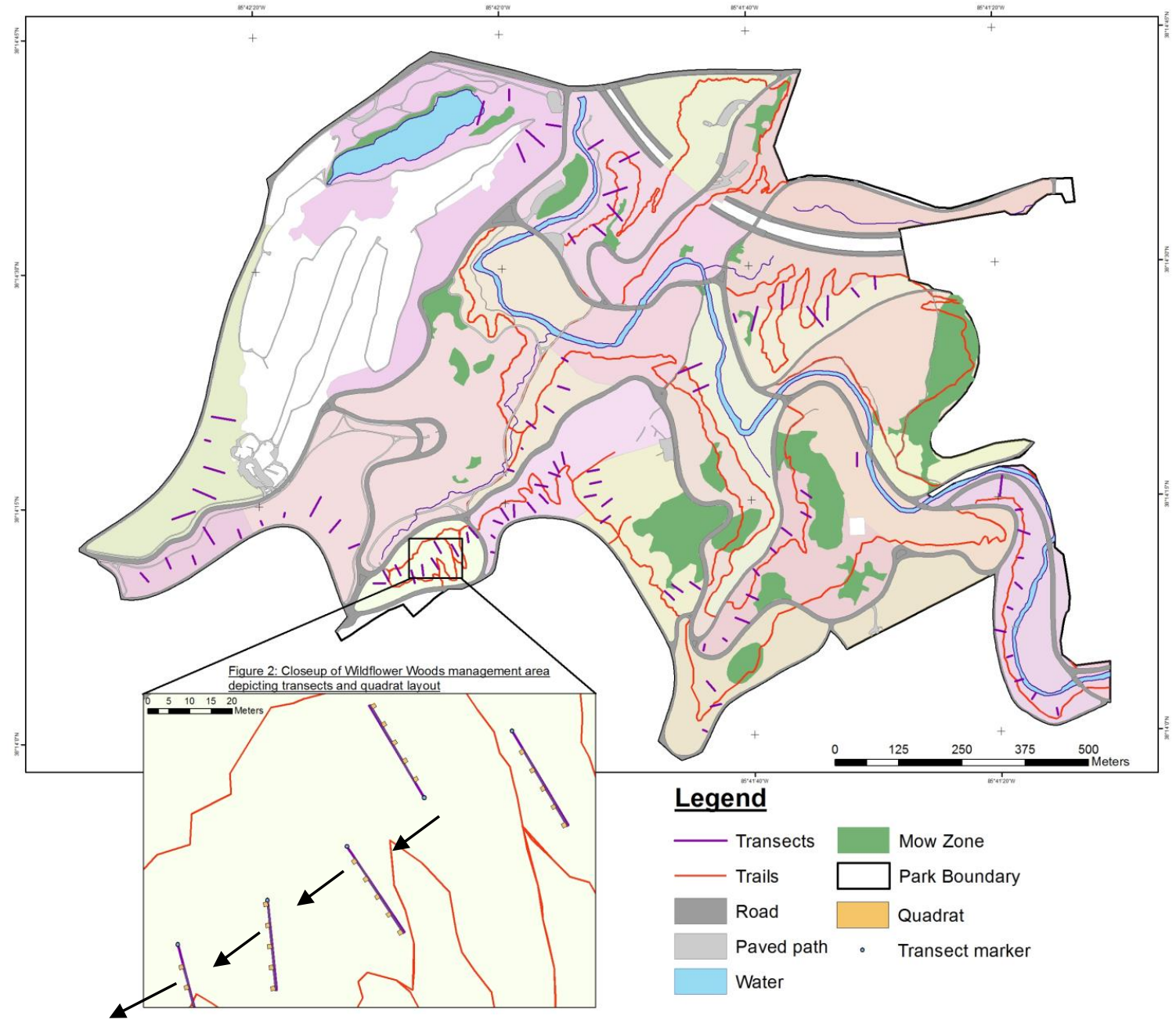

Figure 2. Location of transects that were found and re-sampled in 2014. Inset shows the direction of movement from pin-to-pin, which subsequently determined the transect bearing and quadrat placement (always on the right hand side of the transect). Pastel colors represent sub-units within the larger management areas, which were used for proper identification of transects. 

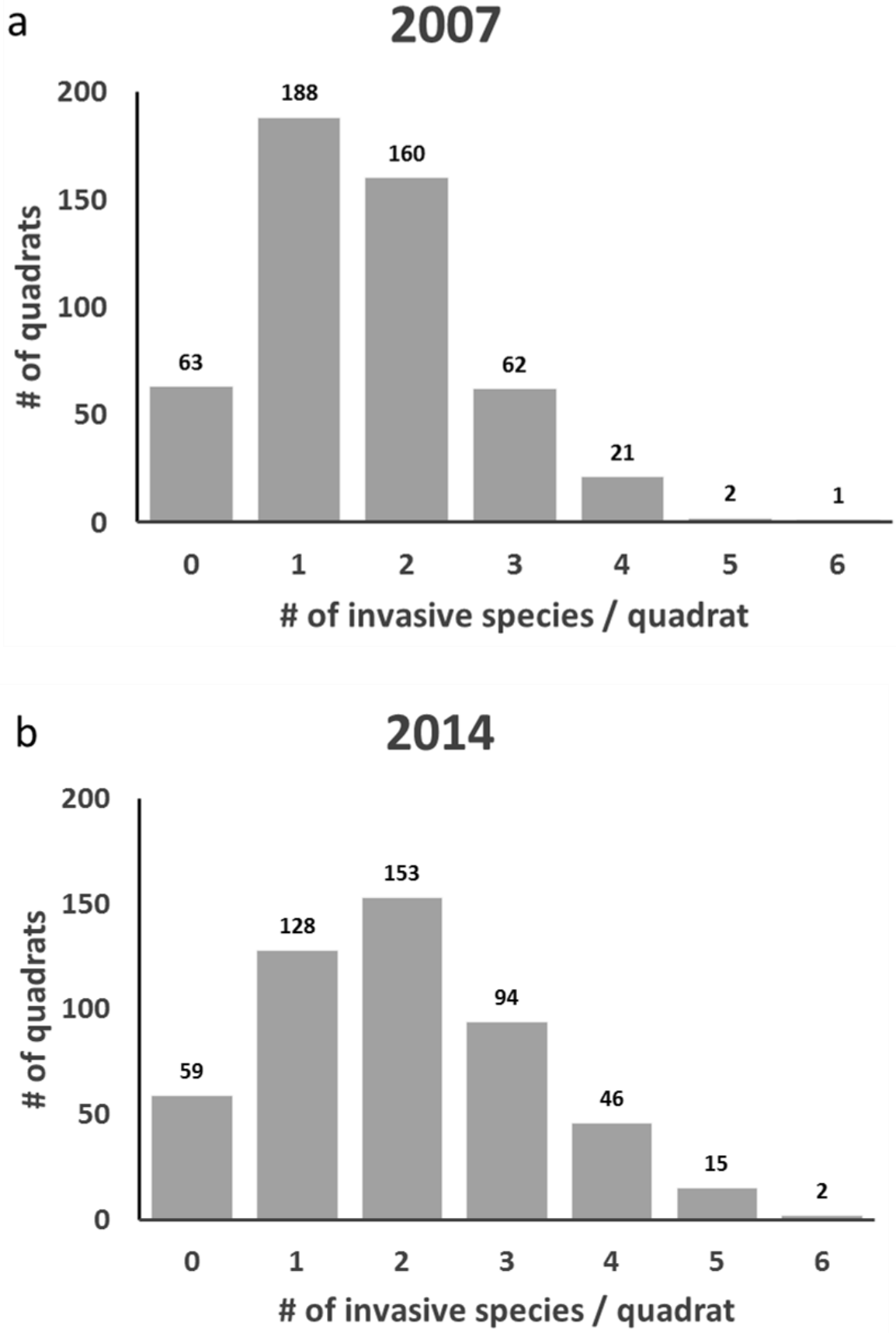

Figure 3. Frequency distribution of the number of quadrats with zero to 6 invasives per quadrat in (a) 2007 before invasive shrub and vine removals and in (b) 2014, 6 to 7 years after invasive these removals. 


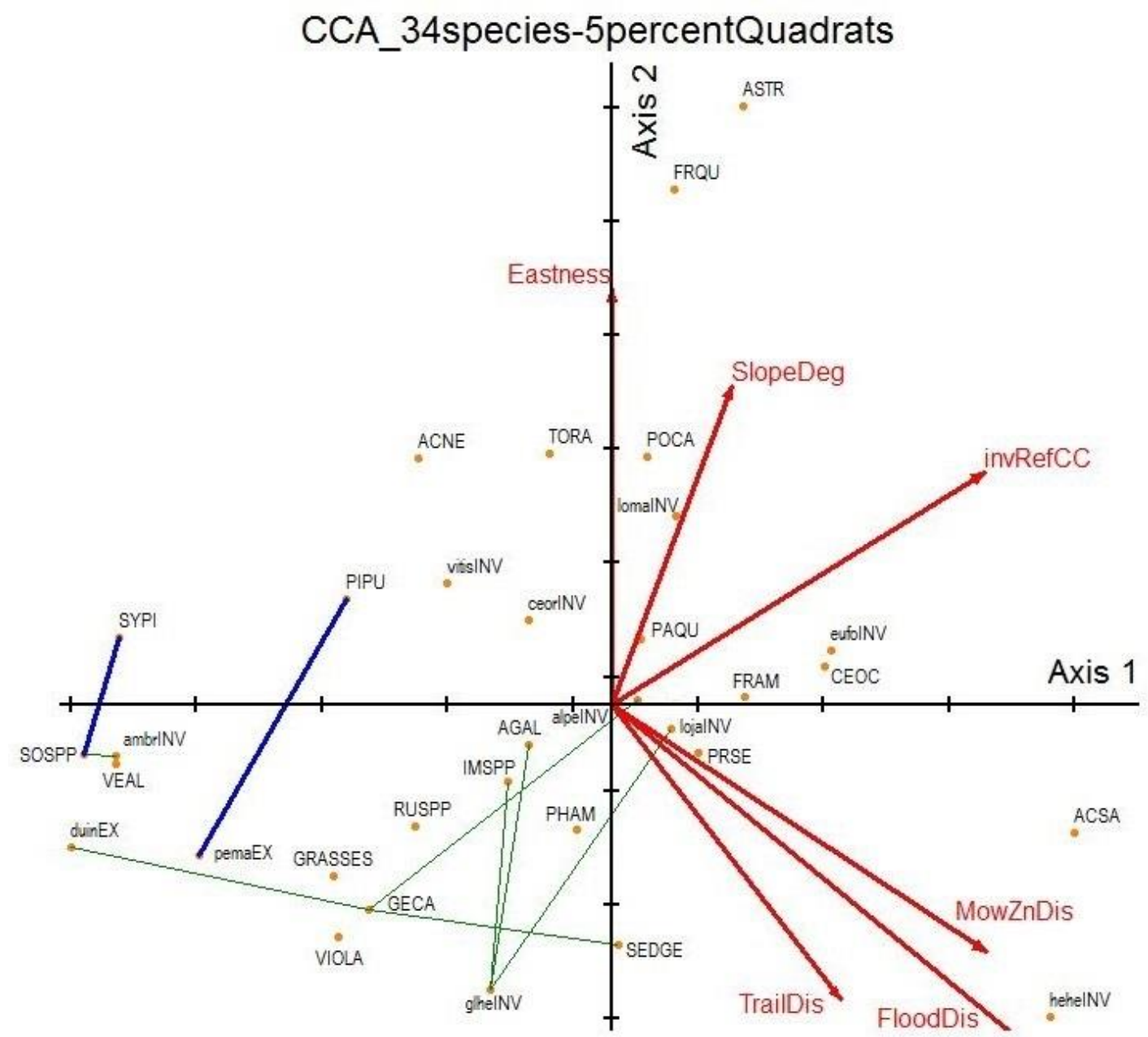

Figure 4. Combined Community: Axes 1 and 2 of ordination of species in environmental space, with points representing the centroid of species (see Appendix 1 for species identities based on letter codes). All CAPS indicate native species/taxa, while non-native species/taxa have been emphasized with lowercase letters, followed by INV if one of the original 11 invasives, or EX if non-native but not one of the original 11 invasives). Lines connecting species are weak (thin) and strong (thick) association lines indicating a tendency for these species to co-occur. Red arrows are the biplot overlays showing the strongest environmental variables (biplot cutoff $=0.3$ ) that determined the axes. 


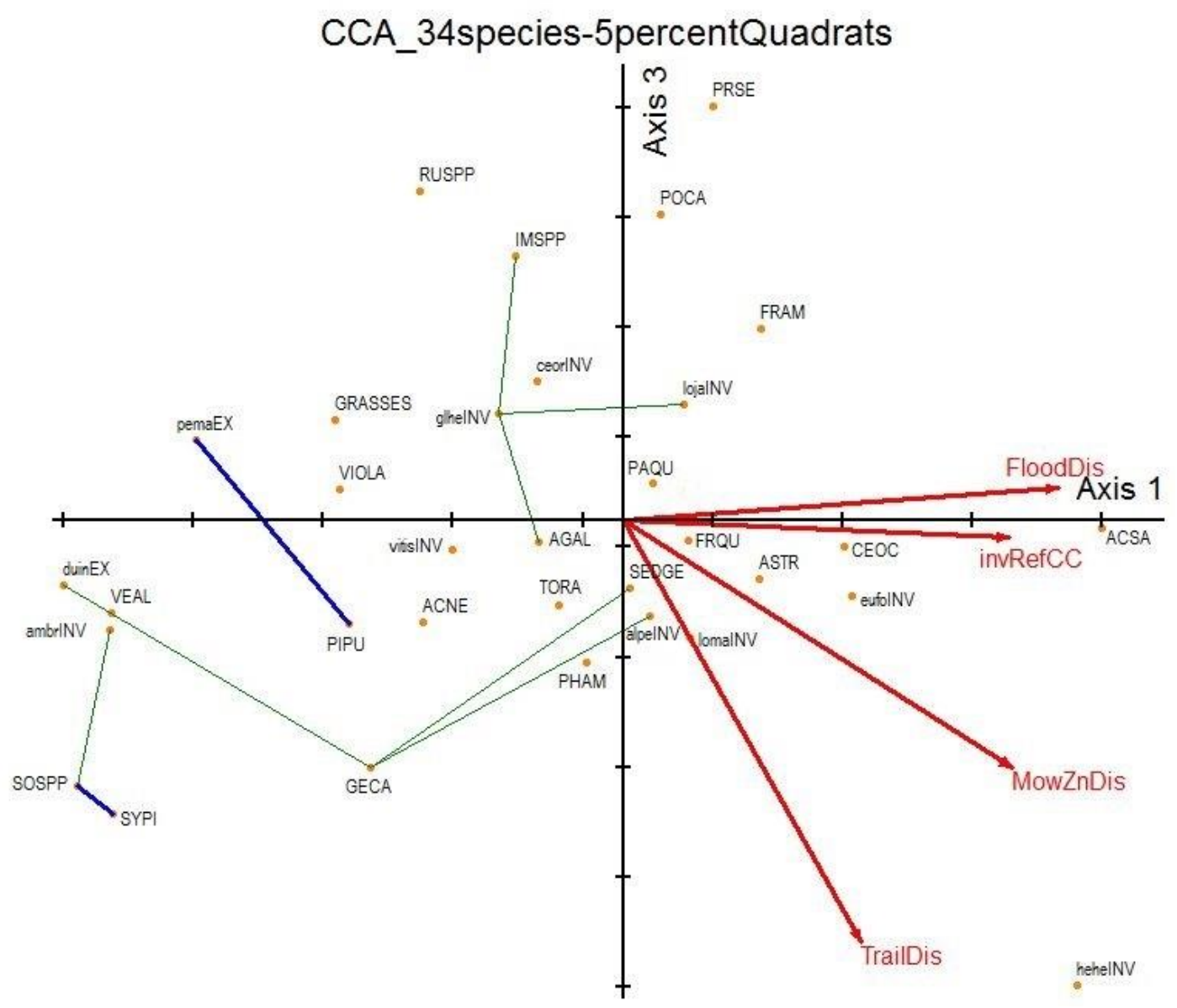

Figure 5. Combined Community: Axes 1 and 3 of ordination of species in environmental space, with points representing the centroid of species (see Appendix 1 for species identities based on letter codes). All CAPS indicate native species/taxa, while non-native species/taxa have been emphasized with lowercase letters, followed by INV if one of the original 11 invasives, or EX if non-native but not one of the original 11 invasives). Lines connecting species are weak (thin) and strong (thick) association lines indicating a tendency for these species to co-occur. Red arrows are the biplot overlays showing the strongest environmental variables (biplot cutoff $=0.3$ ) that determined the axes. 


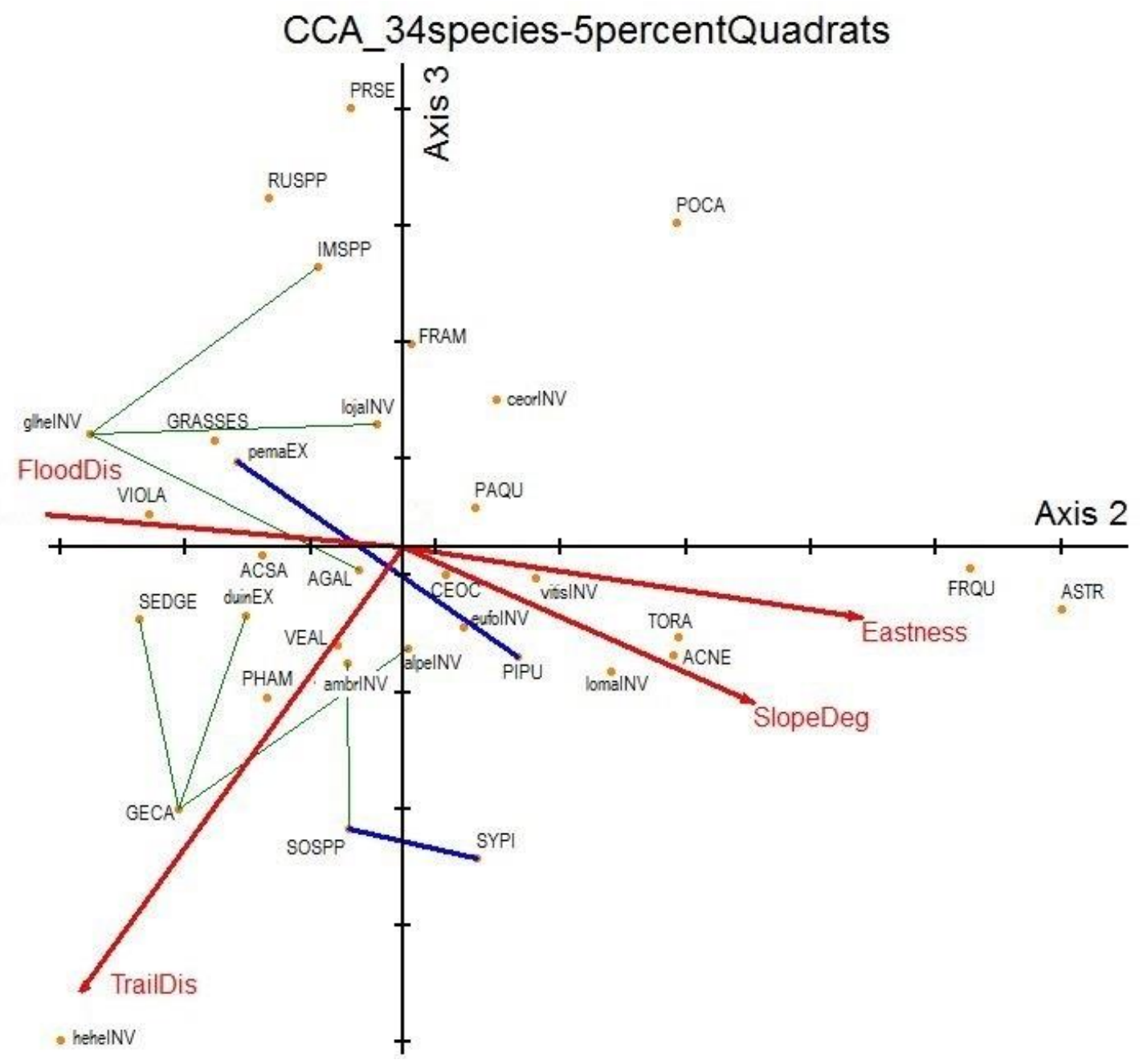

Figure 6. Combined Community: Axes 2 and 3 of ordination of species in environmental space, with points representing the centroid of species (see Appendix 1 for species identities based on letter codes; non-native species/taxa have been emphasized with lowercase letters, followed by INV if one of the original 11 invasives, or EX if nonnative but not one of the original 11 invasives). Lines connecting species are weak (thin) and strong (thick) association lines indicating a tendency for these species to co-occur. Red arrows are the biplot overlays showing the strongest environmental variables (biplot cutoff $=0.3$ ) that determined the axes. 


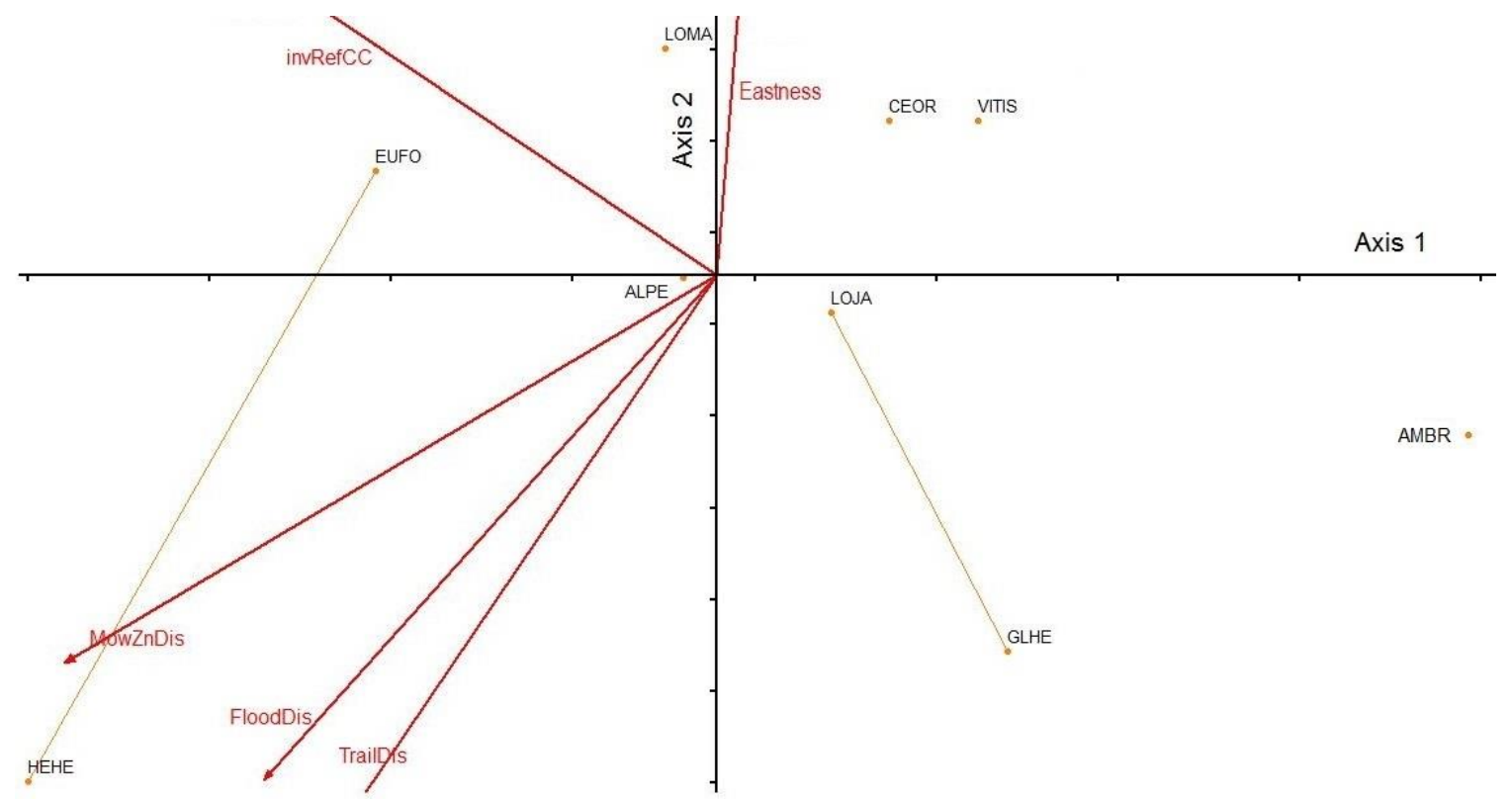

Figure 7. Axes 1 and 2 of ordination of invasive species in environmental space. Points represent the centroids of species. Lines connecting species are weak (thin) and strong (thick) association lines indicating a tendency for these species to co-occur. Red arrows are the biplot overlays showing the strongest environmental variables (biplot cutoff $=0.3$ ) that determined the axes. 


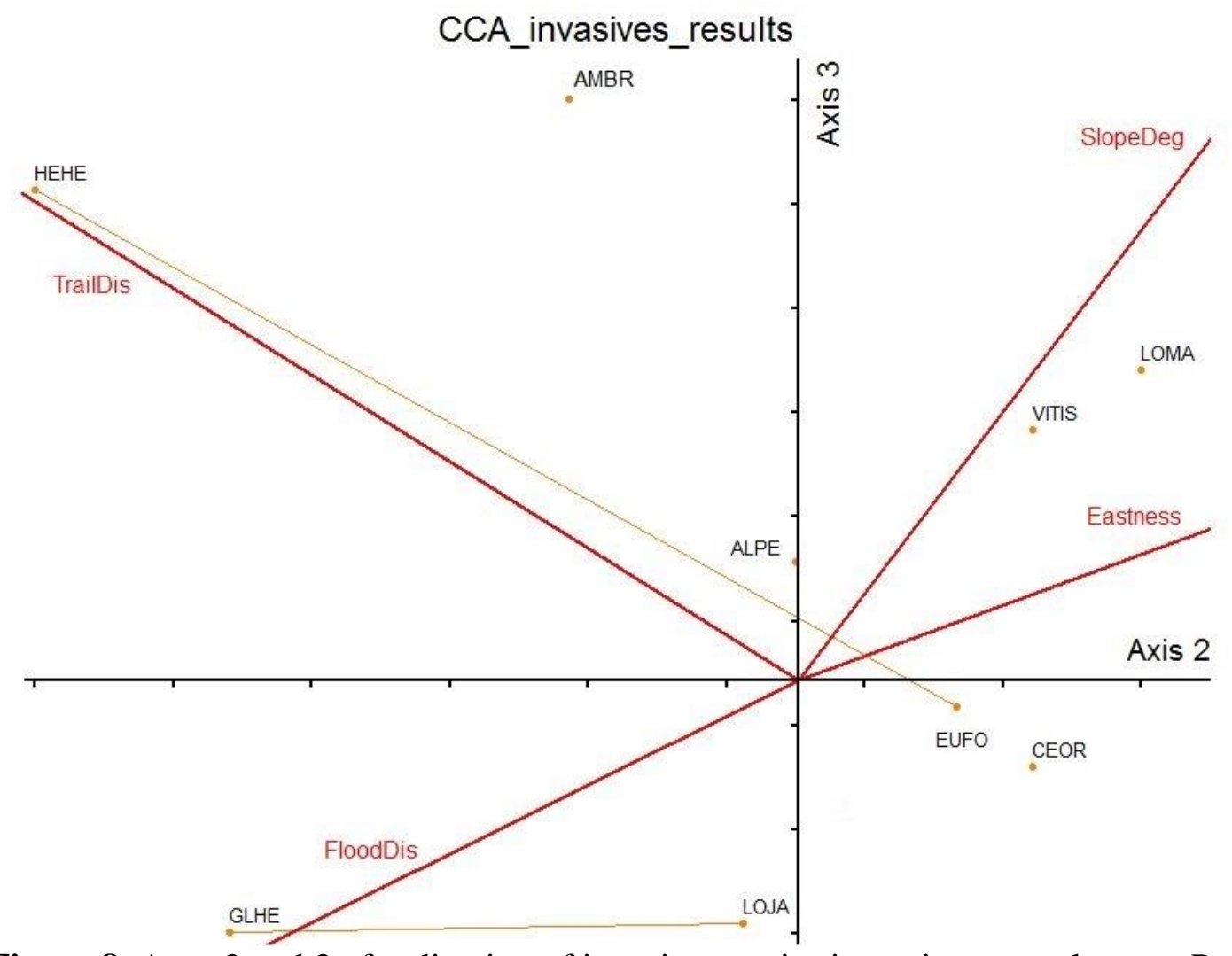

Figure 8. Axes 2 and 3 of ordination of invasive species in environmental space. Points represent the centroids of species. Lines connecting species are weak (thin) and strong (thick) association lines indicating a tendency for these species to co-occur. Red arrows are the biplot overlays showing the strongest environmental variables (biplot cutoff $=0.3$ ) that determined the axes. 
Appendix 1. Table containing letter codes for all 123 taxa included in the study. Scientific names are the taxonomic level of classification used for each given taxa (e.g. Genus spp. for grouping at the genus level, Juncaceae for grouping at the family level, etc.). CV scores are Conservatism Values for native Kentucky plants and range from 010. Asterisk* indicates non-native species, N/A means CV score not applicable to that taxon. The two species of Solidago that were identified had very different CV scores; $S$. flexicaulis occurred in only 2 quadrats and was grouped with other unidentified Solidago species. CV scores are as follows:

0 - Ruderal areas only

1 - Mostly ruderal areas, small chance of natural areas

2 - Occurs in both ruderal and natural areas equally

3 - Occurs slightly more in natural areas than ruderal areas

4 - Strong preference for natural areas

5 - Only in lower quality natural areas, no ruderal areas.

6 - Weak preference for high-quality natural areas.

7 - Medium preference for high-quality natural areas.

8 - Higher preference for high-quality natural areas.

9 - Very high preference for high-quality natural areas.

10 - Only occurs in high-quality natural areas.

\begin{tabular}{|c|c|c|c|c|c|}
\hline \multirow[b]{2}{*}{ Code } & \multirow[b]{2}{*}{ Species } & \multirow[b]{2}{*}{ Habit } & \multicolumn{2}{|r|}{ CV } & \multirow[b]{2}{*}{ Family } \\
\hline & & & Status & Score & \\
\hline ACRH & Acalypha rhomboidea & herb & native & 1 & Euphorbiaceae \\
\hline ACNE & Acer negundo & tree & native & 1 & Aceraceae \\
\hline ACNI & Acer nigrum & tree & native & 6 & Aceraceae \\
\hline ACPL & Acer platanus & tree & non-native & $*$ & Aceraceae \\
\hline ACSA & Acer saccharum & tree & native & 4 & Aceraceae \\
\hline AEGL & Aesculus glabra & tree & native & 3 & Hippocastanaceae \\
\hline AGAL & Ageratina altissima & herb & native & 2 & Asteraceae \\
\hline AIAL & Ailanthus altissima & tree & invasive & $*$ & Simaroubaceae \\
\hline AKQU & Akebia quinata & vine & invasive & $*$ & Lardizabalaceae \\
\hline ALPE & Alliaria petiolata & herb & invasive & $*$ & Brassicacceae \\
\hline ALBU & Allium burdickii & herb & native & 8 & Liliaceae \\
\hline ALCA & Allium canadense & herb & invasive & $*$ & Liliaceae \\
\hline
\end{tabular}




\begin{tabular}{|c|c|c|c|c|c|}
\hline AMAR & Ambrosia artemisiifolia & herb & native & 0 & Asteraceae \\
\hline AMTR & Ambrosia trifida & herb & native & 0 & Asteraceae \\
\hline AMBR & Ampelopsis brevipedunculata & vine & invasive & $*$ & Vitaceae \\
\hline AQCA & Aquilegia canadensis & herb & native & 7 & Ranunculaceae \\
\hline ARTR & Arisaema triphyllum & herb & native & 6 & Araceae \\
\hline ASCA & Asarum canadense & herb & native & 6 & Aristolochiaceae \\
\hline ASTR & Asimina triloba & tree & native & 7 & Annonaceae \\
\hline BIFR & Bidens frondosa & herb & native & 1 & Asteraceae \\
\hline BICA & Bignonia capreolata & vine & native & 6 & Bignoniaceae \\
\hline Moss & Bryophyta & moss & N/A & N/A & Bryophyta \\
\hline CACO & Carya cordiformis & tree & native & 5 & Juglandaceae \\
\hline CATH & Caulophyllum thalictroides & herb & native & 7 & Berberidaceae \\
\hline CEOR & Celastrus orbiculatus & vine & invasive & $*$ & Celastraceae \\
\hline CEOC & Celtis occidentalis & tree & native & 3 & Ulmaceae \\
\hline CECA & Cercis canadensis & tree & native & 3 & Caesalpiniaceae \\
\hline CLTE & Clematis terniflora & vine & invasive & $*$ & Ranunculaceae \\
\hline coco & Commelina communis & herb & invasive & $*$ & Commelinaceae \\
\hline COMA & Conium maculatum & herb & invasive & $*$ & Apiaceae \\
\hline COFL & Cornus florida & tree & native & 5 & Cornaceae \\
\hline CRCA & Cryptotaenia canadensis & herb & native & 4 & Apiaceae \\
\hline Sedge & Cyperaceae & sedge & N/A & N/A & Cyperaceae \\
\hline DIOP & Dioscorea oppositifolia & vine & invasive & $*$ & Discoreaceae \\
\hline DUIN & Duchesnea indica & herb & invasive & * & Rosaceae \\
\hline ELCA & Elephantopus carolinianus & herb & native & 2 & Asteraceae \\
\hline ERHI & Erechtites hieracifolia & herb & native & 1 & Asteraceae \\
\hline ERSP & Erigeron $s p$. & herb & native & 1 & Asteraceae \\
\hline EUAL & Euonymus alatus & shrub & exotic & * & Celastraceae \\
\hline EUFO & Euonymus fortuneii & vine & invasive & * & Celasteraceae \\
\hline FAGR & Fagus grandifolia & tree & native & 5 & Fagaceae \\
\hline FAVI & Fatoua villosa & herb & invasive & $*$ & Asteraceae \\
\hline FRVE & Fragaria vesca & herb & native & 2 & Rosaceae \\
\hline FRAM & Fraxinus americana & tree & native & 4 & Oleaceae \\
\hline FRPE & Fraxinus pennsylvanica & tree & native & 3 & Oleaceae \\
\hline FRQU & Fraxinus quadrangulata & tree & native & 7 & Oleaceae \\
\hline GECA & Geum canadense & herb & native & 2 & Rosaceae \\
\hline GEVE & Geum vernum & herb & native & 3 & Rosaceae \\
\hline GIBI & Ginkgo biloba & tree & exotic & * & Ginkgoaceae \\
\hline GLHE & Glehcoma hederacea & herb & invasive & * & Lamiaceae \\
\hline GYDI & Gymnocladus dioicus & tree & native & 6 & Caesalpiniaceae \\
\hline HEHE & Hedera helix & vine & invasive & $*$ & Araliaceae \\
\hline
\end{tabular}




\begin{tabular}{|c|c|c|c|c|c|}
\hline HISY & Hibiscus syriacus & shrub & exotic & $*$ & Malvaceae \\
\hline HYAP & Hydrophyllum appendiculatum & herb & native & 5 & Hydrophyllaceae \\
\hline HYCA & Hydrophyllum canadense & herb & native & 5 & Hydrophyllaceae \\
\hline ILOP & Ilex opaca & tree & native & 5 & Aquifoliaceae \\
\hline IMSPP & Impatiens spp. & herb & native & 2 & Balsaminaceae \\
\hline JUNI & Juglans nigra & tree & native & 4 & Juglandaceae \\
\hline Rush & Juncaceae & rush & N/A & $\mathrm{N} / \mathrm{A}$ & Juncaceae \\
\hline KOPA & Koelreuteria paniculata & tree & exotic & $*$ & Sapindiaceae \\
\hline LACA & Laportea canadensis & herb & native & 4 & Urticaceae \\
\hline LISP & Ligustrum sp. & shrub & invasive & $*$ & Oleaceae \\
\hline LIBE & Lindera benzoin & shrub & native & 5 & Lauraceae \\
\hline LIST & Liquidambar styraciflua & tree & native & 3 & Hamamelidaceae \\
\hline LITU & Liriodendron tulipifera & tree & native & 2 & Magnoliaceae \\
\hline LOJA & Lonicera japonica & vine & invasive & $*$ & Caprifoliaceae \\
\hline LOMA & Lonicera maackii & shrub & invasive & $*$ & Caprifoliaceae \\
\hline LYNU & Lysimachia nummularia & herb & invasive & $*$ & Primulaceae \\
\hline MARA & Maianthemum racemosum & herb & native & 5 & Liliaceae \\
\hline MECA & Menispermum canadense & vine & native & 4 & Menispermaceae \\
\hline MOAL & Morus alba & tree & invasive & $*$ & Urticaceae \\
\hline OSCL & Osmorhiza claytonii & herb & native & 5 & Apiaceae \\
\hline OSVI & Ostrya virginiana & tree & native & 6 & Betulaceae \\
\hline OXST & Oxalis stricta & herb & native & 0 & Oxalidaceae \\
\hline PAQU & Parthenocissus quinquefolia & vine & native & 2 & Vitaceae \\
\hline PEFR & Perilla frutescens & herb & invasive & $*$ & Lamiaceae \\
\hline PEMA & Persicaria maculosa & herb & invasive & $*$ & Polygonaceae \\
\hline PHAM & Phytolacca americana & herb & native & 1 & Phytolaccaceae \\
\hline PIPU & Pilea pumila & herb & native & 3 & Pinaceae \\
\hline PLMA & Plantago major & herb & invasive & $*$ & Plantaginaceae \\
\hline PLOC & Platanus occidentalis & tree & native & 3 & Platanaceae \\
\hline Grasses & Poaceae & grass & N/A & $\mathrm{N} / \mathrm{A}$ & Poaceae \\
\hline POPE1 & Podophyllum peltatum & herb & native & 6 & Berberidaceae \\
\hline POBI & Polygonatum biflorum & herb & native & 5 & Liliaceae \\
\hline POPE2 & Polygonum pennsylvanicum & herb & native & 2 & Polygonaceae \\
\hline POVI & Polygonum virginianum & herb & native & 3 & Polygonaceae \\
\hline POCA & Polymnia canadensis & herb & native & 4 & Asteraceae \\
\hline PRSE & Prunus serotina & tree & native & 3 & Rosaceae \\
\hline Fern & Pteridophyta & fern & native & 7 & Dryopteridaceae \\
\hline PYCA & Pyrus calleryana & tree & exotic & $*$ & Rosaceae \\
\hline QUAL & Quercus alba & tree & native & 5 & Fagaceae \\
\hline QUMU & Quercus muehlenbergii & tree & native & 5 & Fagaceae \\
\hline QUPR & Quercus prinoides & $\begin{array}{l}\text { tree } \\
68\end{array}$ & native & 6 & Fagaceae \\
\hline
\end{tabular}




\begin{tabular}{|c|c|c|c|c|c|}
\hline QURU & Quercus rubra & tree & native & 6 & Fagaceae \\
\hline RHCA & Rhamnus cathartica & shrub & invasive & $*$ & Rhamnaceae \\
\hline RHSC & Rhodotypos scandens & shrub & invasive & $*$ & Rosaceae \\
\hline RHGL & Rhus glabra & tree & native & 2 & Anacardiaceae \\
\hline ROPS & Robinia pseudoacacia & tree & native & 1 & Fabaceae \\
\hline ROMU & Rosa multiflora & shrub & invasive & $*$ & Rosaceae \\
\hline RUSPP & Rubus spp. & shrub & native & 2 & Rosaceae \\
\hline RUOB & Rumex obtusifolius & herb & invasive & $*$ & Polygonaceae \\
\hline SACA & Sambucus canadensis & shrub & native & 2 & Caprifoliaceae \\
\hline SAOD & Sanicula odorata & herb & native & 4 & Apiaceae \\
\hline SAAL & Sassafras albidum & tree & native & 2 & Lauraceae \\
\hline SMRO & Smilax rotundifolia & vine & native & 4 & Smilacaceae \\
\hline SOPT & Solanum ptychanthum & herb & native & $*$ & Solanaceae \\
\hline SOSPP & Solidago spp. & herb & native & 1 & Asteraceae \\
\hline-- & Solidago flexicaulis & herb & native & 6 & Asteraceae \\
\hline STME & Stellaria media & herb & invasive & $*$ & Caryophyllaceae \\
\hline SYOR & Symphoricarpos orbiculatus & shrub & native & 2 & Caprifoliaceae \\
\hline SYPI & Symphyotrichum pilosum & herb & native & 0 & Asteraceae \\
\hline TAOF & Taraxacum officinale & herb & invasive & $*$ & Asteraceae \\
\hline TECA & Teucrium canadense & herb & native & 3 & Lamiaceae \\
\hline TIAM & Tilia americana & tree & native & 5 & Tiliaceae \\
\hline TORA & Toxicodendron radicans & vine & native & 2 & Anacardiaceae \\
\hline TRSE & Trillium sessile & herb & native & 5 & Liliaceae \\
\hline ULRU & Ulmus rubra & tree & native & 4 & Ulmaceae \\
\hline VETH & Verbascum thapsus & herb & invasive & $*$ & Scrophulariaceae \\
\hline VEAL & Verbesina alternifolia & herb & native & 2 & Asteraceae \\
\hline VEGI & Vernonia gigantea & herb & native & 2 & Asteraceae \\
\hline VIDE & Viburnum dentatum & shrub & native & 7 & Caprifoliaceae \\
\hline VIMI & Vinca minor & vine & invasive & $*$ & Apocynaceae \\
\hline VIOLA & Viola spp. & herb & native & 0 & Violaceae \\
\hline VISP & Vitis spp. & vine & invasive & 3 & Vitaceae \\
\hline
\end{tabular}




\title{
CURRICULUM VITA
}

NAME: $\quad$ Eric Richard Moore

ADDRESS: University of Louisville, Department of Biology

139 Life Sciences Bldg.

Louisville, KY 40292

DOB: $\quad$ Panama City, FL - July 14, 1987

\author{
EDUCATION \\ \& TRAINING: B.S., Biology \\ University of Louisville \\ 2005-2013 \\ M.S., Biology \\ University of Louisville \\ 2013-Present
}

AWARDS: Dean's List (multiple semesters)

PROFESSIONAL SOCIETIES: Kentucky Association of Mapping Professionals

Kentucky Academy of Science

INVITED PRESENTATIONS: Poster presented at the Kentucky Academy of Science's annual conference in November 2013.

Moore E, Taylor B, Carreiro M. (August 2013). The effect of invasive shrub and vine removal on tree seedling and sapling recruitment in an urban park woodland.

Guest Lecturer, Conservation Biology course. Lecture topic: Species Invasions. October 2014. 